\title{
A Note on the Ongoing Processes of Commodification: From the Audience Commodity to the Social Factory
}

\author{
Jernej Prodnik
}

\author{
Faculty of Social Sciences, Social Communication Research Centre, University of Ljubljana, Slo- \\ venia jernej.prodnik@fdv.uni-lj.si
}

\begin{abstract}
The commodity-form played an important, if often overlooked, role in the studies of capitalism. Processes of transforming literally anything into a privatized form of (fictitious) commodity that is exchanged in the circulation process are of fundamental importance for the rise and reproduction of capitalism. At the same time the commodity, as the "cell-form of capitalism", has played a crucial role throughout Marx's oeuvre. The central aim of the paper is to demonstrate how the commodity-form develops in his works (both as a part of his "global" argument and in the context of historical changes) and what role it plays in some of the key works of critical theory. Furthermore, the aim is to show how this topic was approached in critical communication studies and has been analysed in the political economy of communication. The latter is done principally through a reappraisal of the "blind spot debate" initiated by Dallas W. Smythe and the audience commodity thesis, in which it was raised. This long-lasting debate, which at least indirectly continues to date, can be seen as an invaluable source for practices and ideas connected to both Marxian-inspired critical communication studies and to a serious analysis of the continuing commodification of different spheres of society and its increasing pervasiveness in contemporary life. In the last section, these findings are connected to some of the recent neo-Marxist approaches, especially to the findings of the authors coming from the autonomist (post-operaist) movement. Insights into this intellectual strand can provide an understanding of the ongoing commodification processes, while also offering possibilities of convergence with Smythe's approach.
\end{abstract}

Keywords: Commodity-form, Commodification, Abstraction, Political economy of communication, Critique of political economy, Social factory, Audience commodity, Internet, Communication capitalism, Capitalism, Critical communication studies.

\section{Introduction}

Commodity-form and commodification have played an important, if often overlooked, role in critical studies of capitalist societies. Authors such as Adorno (2001/1991), Debord (1970, ch.2), Lukács (1971), Sohn-Rethel (1972; 1978), Cleaver (2000/1979), Wallerstein (1983, ch.1), Huws (2003), and Postone (2003/1993) have focused their attention on this so-called "cell-form of capitalism", as the commodity has been characterised in Marx's writing. Commodity-form ${ }^{1}$ was a key category in Marx's work and it played a crucial role throughout his whole oeuvre, from his early writings on political economy to his latter conceptualisations that included full development of the role it carries in constitution and reproduction of the capitalist societies (Marx and Engels 1976; 1987; Marx 1993/1858; 1990/1867; see also Murdock 2006; Barbalet 1983, 90f.). Even in post-modernity, commodification processes can be seen as being amongst crucial preconditions for the general preservation of capitalist social relations and continuing expansion of capital. Historically speaking, processes of transforming literally anything into a privatized form of (fictitious) commodity that can be exchanged in the market are thus of critical importance for both the rise and continuing reproduction of capitalism. It is only via the production of commodities for exchange that capitalists can extract surplus value from labour (Huws 2003, 61).

The main aim of this paper is to demonstrate how the role of commodity-form and commodification were analysed in the key works of heterodox critical theory (both in Marx's work and in the writings of his successors) and what the main consequences are of the global universalisation of the commodity-form for society and social relations according to these authors. This will be done in the following three sections of this paper, where I will look closely at how the commodity-form was analysed by Marx throughout his oeuvre (Section 2) and how this corresponds to the wider historical transformations and the constitution of capitalist society. In Section 3, a closer look at how different critical authors following Marx analysed these processes will help to clarify the role commodification plays in the emergence of commodity fetishism and how corresponding exchange contributes to human individualisation (Section 3). In Section 4, this argument will be further extended by

\footnotetext{
${ }^{1}$ Sohn-Rethel takes a close look at the term "form", which he defines as being time-bound: "It originates, dies and changes with time" $(1978,17)$. This supposedly distinguishes Marx and his dialectical thought from all other schools of thinking. For Jameson $(2011,35)$ the word "form" prevents "thingification" or reification of money, exchange-value etc., that are first and foremost social relations.
} 
demonstrating that there is now an enduring global commodification of everything, including culture, creativity, information, and diverging types of communication; these categories are becoming fundamental in what could also be called capitalist informational societies. Furthermore, I will be interested in how this topic was approached in critical communication studies, especially in the (critique of) political economy of communication (see Mosco 2009, ch.7). The latter will first and foremost be done through a reappraisal of the "blind spot debate" (and the concurring "audience commodity" thesis), which also played a crucial role in the development of political economy of communication as such ${ }^{2}$. Section 5 will help to clarify how commodification, with the help of digitalisation, is able to penetrate into communication processes and thus construct new commodities. In the last part of the text, in Section 6, these findings will be connected to some of the recent neoMarxist approaches, especially to the findings of the authors coming from the autonomist/postoperaist movement. I will try to show how insights into this intellectual strand can provide an understanding of the ongoing commodification processes through concepts such as communicative, biolinguistic capitalism, and social factory, and how it therefore offers several convergence points with political economy of communication.

The main presupposition of this text will be that there is an increasing significance of communication in post-Fordist capitalism. Communication spreads into, and emanates from, all nooks of the social fabric; this notion, however, seems especially crucial in the current historical epoch, which seems to be completely permeated by communication on all levels of human and social life (i.e. notions regarding the mediatisation of society). At the same time, however, communication is also becoming almost fully commodified. Post-operaist thought claims that communication, or even language-capacity as such, gained hegemonic primacy in contemporary society, while also constituting a new source of capitalist accumulation. Several of the assertions pointed out by Marx, his early successors, and authors contributing to the "blind-sport debate" therefore need to be raised again because of the significantly (but not fundamentally) changed social context and technological changes that are enabling further expansion of commodification.

\section{The Role of the Commodity-Form in the Writings of Karl Marx}

According to Lukács (1971), it was not a coincidence that Marx began his major works with an analysis of the commodity when he decided to lay out the totality of capitalist society. The problem of commodities should, according to Lukács, in fact be regarded "as the central, structural problem of capitalist society in all its aspects" (Lukács 1971, 83). It should therefore not be seen either in isolation or even as a central problem of only economics, which consequently means it is difficult to ignore this issue when providing a critique of the really existing social relations. For Marx $(1990 / 1976,90)$, the commodity-form, which is the product of abstract human labour (both being historical categories bound to capitalist societies), is one of the economic cell-forms of the current historical epoch. These categories enabled Marx to analyse capitalism in its most abstract form, but also at its most fundamental level. It is worth mentioning that he saw abstraction as a chief (and perhaps only possible) means of a scientific analysis of society, which, together with dialectics, enables the enquirer to go beyond mere appearances of things ${ }^{3}$.

This crucial role of the commodity can be seen from Marx's earliest writings on political economy to his later conceptualisations, and many authors believed this to be the pre-eminent starting point for any analysis of society under capitalism (e.g. Lukács 1971; Sohn-Rethel 1978; Postone 2003/1993). In Marx's early writings, for example in The Poverty of Philosophy, published in French in 1847 (Marx and Engels 1976, 105-212), he dealt with the use and especially exchange-value of

\footnotetext{
2 Dallas W. Smythe initiated this debate in 1977 with his article Communications: Blindspot of Western Marxism, which was followed by several replies and corrections, most notably by Murdock (1978) a year later and Smythe's (1978) rejoinder to Murdock in the same year.

${ }^{3}$ Experiments in natural sciences are replaced by the power of abstraction in social sciences. Theory is, for example, always an abstraction from empirical reality, even if it must inevitably build on this same reality. Marx furthermore pointed out that "all science would be superfluous if the form of appearance of things directly coincided with their essence" (Marx 1991/1981, 956). It is precisely here, according to him, that "vulgar economics feels completely at home, these relationships appearing all the more self-evident to it, the more their inner connections remain hidden". (ibid.) According to Eagleton $(1996,6)$, there is always a hiatus between how things actually are and how they seem; there is, so to say, a difference between essence and appearance, because the latter needs to be penetrated or bypassed to understand reality (see Barbalet 1983, 23f.; Postone 2003/1993). It could therefore be claimed that one of the central goals of both dialectics and abstraction is to take analysis beyond sole appearances of things, which is impossible with a mere analysis of concrete reality (where several mechanisms operate at the same time). In most cases, things are not simply opaque or what they seem on the surface. Barbalet $(1983,24)$ points out it is exactly the role commodity fetishism (which is dealt with later in this text) plays in society that demonstrates this point in its entirety. For a more detailed analysis of contradictions between appearances and reality (and questions concerning transphenomenality and counter-phenomenality) see also Collier's $(1994,6 \mathrm{f}$.) interpretation of the meta-theoretical position of critical realism.
} 
commodities, the latter being an inexorable part of commodity production in the societies of producers who exchange their commodities. It is around this time that he defined the law of value of commodities as being determined by the labour time inherent in them (he still wrote of labour and not labour power, which is a more precise conceptualisation also present in his later writings). Labour time is therefore the measure of value, and labour, as Marx pointed out (Marx and Engels 1976, 130), was itself a commodity: labour-commodity, bought and sold in the market. If there is an exchange of two products (commodities), there is an exchange of equal quantities of labour, or more precisely, exchange of labour time (Marx and Engels 1976, 126). As he famously put it: "Time is everything, man is nothing; he is, at the most, time's carcase. Quality no longer matters. Quantity alone decides everything; hour for hour, day for day" (Marx and Engels 1976, 127). This, of course, is a historical specificity of capitalist societies and not some eternal justice, as Proudhon at the time thought it was.

According to Murdock, it was already in the time when Marx wrote The Poverty of Pjhilosophy that he identified "commodification as the central driving force propelling capitalism's expansion" (Murdock 2006, 3). It was consequently only a matter of time before all things, from physical to moral, that might never have been sold or acquired before in the history of humankind, are brought to the market and exchanged (ibid.; see also Marx and Engels 1976, 113). The role of the commodity-form in the Marxian critique of political economy can therefore hardly be overstated even in Marx's earliest writings. It can be regarded as an indispensable part of capitalism, the blood in its cycle of accumulation, which is essential for its continuing reproduction ${ }^{4}$. This also demonstrates that the commodity-form is an unavoidable part of a serious critique of capitalism, the line of thinking which was considerably extended by critical communication studies, especially by authors following Smythe's path. For Mosco, for example, the commodification process, defined as "the process of transforming use-values into exchange-values" (Mosco 2009, 129, ch. 7), is one of the central processes that make up the starting point for the political economy of communication.

Even though Marx had already analysed the commodity-form in his earliest writings, it is especially in his later works that he provided a detailed overview of the role it has, not only in the reproduction of capitalism, but also in social life as such. His perhaps most detailed account was in $A$ Contribution to the Critique of Political Economy (see Marx and Engels 1987, 257-417), which was written between 1858 and 1859, and served as a basis for his elaboration of the commodity in the first volume of Capital (Marx 1990/1867). In these two works, all of the so-called cell-forms of capitalist economy are fully laid out, including the difference between abstract labour, which is the source of exchange-value, and concrete labour, which can produce an infinite variety of different use-values and is the source of actual material wealth. Both exchange-value, or simply value, and abstract labour, can be seen as such historical cell-forms, and both are indispensable parts of commodity-form ${ }^{5}$. All of these categories form the basis of the capitalist economy in the most abstract sense. According to Marx, the key difference between abstract and concrete labour is that "labour positing exchange-value is abstract universal and uniform labour", whereas "labour positing use-value is concrete and distinctive labour, comprising infinitely varying kinds of labour as regards its form and the material to which it is applied". (Marx and Engels 1987, 277) Abstract labour is, so to say, socially useful labour, but one which is without particular use-value to an individual. According to Marx, "universal labour is consequently not a ready-made prerequisite but an emerging result" (Marx and Engels 1987, 286); it exists in commodities in a latent state and only becomes universal as the result of the exchange process. The subject matter of political economy is only the abstract labour and (exchange-) value, while all commodities, regarded as exchange-values, "are merely definite quantities of congealed labour time" (Marx and Engels 1987, 272). This later led Marx to state quite famously that "moments are the elements of profit" (Marx 1990/1867, 352), something that the Taylorist management doctrine developed to the full in the production process.

What seems important here is that even though "exchange-value is a relation between persons; it is however necessary to add that it is a relation hidden by a material veil" (Marx and Engels 1987, 276). This enduring mystification can be seen as one of the most important premises pointed out by Marx and it was later on fully developed through the concept of fetishism. The core ideas of this important presupposition have been developed much earlier though:

\footnotetext{
${ }^{4}$ Seeing commodities as being the blood cells in capitalist accumulation cycle is not only an analogy or a metaphor. In his analysis of the primitive accumulation, Marx in fact points out that "a great deal of capital, which appears today in the United States without any birth-certificate, was yesterday, in England, the capitalized blood of children" (Marx 1990/1976, 920). This, at least implicitly, touches on another important part of his analysis of the commodity-form, namely commodity fetishism. I deal with this issue later in the text (especially in the Section 3.4).

${ }^{5}$ The fact that this particular type of labour is specific only for capitalism and at the same time also fundamental for its functioning, led both Marcuse (1955, 287-295) and Postone (2003/1993) to call for abolition of labour (as known in capitalist societies).
} 


\begin{abstract}
"It is a characteristic feature of labour which posits exchange-value that it causes the social relations of individuals to appear in the perverted form of a social relation between things. [...] Only the conventions of everyday life make it appear commonplace and ordinary that social relations of production should assume the shape of things, so that the relations into which people enter in the course of their work appear as the relations of things to one another and of things to people. This mystification is still a very simple one in the case of a commodity. Everybody understands more or less clearly that the relations of commodities as exchange-values are really the relations of people to the productive activities of one another. The semblance of simplicity disappears in more advanced relations of production. All the illusions of the monetary system arise from the failure to perceive that money, though a physical object with distinct properties, represents a social relation of production" (Marx and Engels 1987, 275f.).
\end{abstract}

There are several important consequences arising from these findings, perhaps most notably the following: While Marx's approach presupposes a need for abstraction to understand how capitalism works (as already pointed out), there is also a real abstraction going on all the time in the existing historical epoch dominated by commodity exchange. "An abstraction is made every day in the social process of production", Marx stresses (Marx and Engels 1987, 272). It is a prerequisite for the constitution of equivalents between factually unequal things. For example, a reduction of different kinds of useful labour into homogeneous abstract labour is unavoidable, because it makes possible monetary exchange between different use-values, which are inherent in commodities. Secondly, these findings have enormous consequences for how social life is constituted in existing societies. Most notably, what is the wider social role of the commodity-form in the concept of commodity fetishism, but also what role does exchange of commodities play in the individualisation of human beings and what types of instrumental rationalisation are developed? These issues will be more thoroughly analysed in the next section.

\title{
3. Commodification and Individualisation: On the Historical Transfor- mations and Commodity Fetishism
}

Commodities, as the products of abstract labour and the worldwide division of labour, obtain definite social character and mediate between individuals and their private labour through the market. As already pointed out, it is not the physical nature of the commodity that matters when it comes to exchanging it, but its social character: what is central is its relation to the other commodities available for exchange (as products of various kinds of useful labour). This relationship between commodities and consequent equivalence between different kinds of labour is constituted through the market. Not only is there a unity of use-value and exchange-value in every commodity, but a commodity can only exist in relation to other commodities through a series of equations. "The exchange process of commodities is the real relation that exists between them. This is a social process which is carried on by individuals independently of one another" (Marx and Engels 1987, 282). As Marx so famously puts it in Capital, this creates a very special social relation that is established through things and forms the basis for commodity fetishism:

"It is nothing but the definite social relation between men themselves, which assumes here, for them, the fantastic form of a relation between things. [...] In other words, the labour of the private individual manifests itself as an element of the total labour of society only through the relations which the act of exchange establishes between products, and, through mediation, between the producers. To the producers, therefore, the social relations between their private labours appear as what they are, i.e. they do not appear as direct social relations between persons in their work, but rather as material [dinglich] relations between persons and social relations between things". (Marx 1990/1867, 165f.)

It is thus social relations between things that mediate between people, consequently producing the key mystification of contemporary social life. Social relations between people are displaced by (and to) something else, in this case, into relations between commodities, simultaneously creating a material veil (which will lead us directly to the questions of individualisation later in the text). The general idea behind both this displacement and commodity fetishism as a whole is relatively simple, but at the same time, it is notoriously difficult (Balibar 2007, 57). This is especially so because 
this concept produces such immensely far-reaching consequences on how we live our lives in (post) modern societies.

\subsection{Historical Changes and the Social Relations in Capitalist Societies}

The key abstract historical arguments made by Marx, which are of crucial importance for the analysis of these consequences for society, have been succinctly presented by Hobsbawm $(2011,130-$ 132). He points out that Marx's theory of social and economic evolution is based on his analysis of (wo)man as a social animal ${ }^{6}$. This can be seen as Marx's fundamental ontological position regarding human nature. Marx's quite abstract account of particular phases of social-economic formations, as depicted in Grundrisse, starts with human beings that labour in nature, changing it and taking from it. This is the basis and natural condition for creation and reproduction of their existence. Taking and changing a part of nature can be seen as perhaps the first kind of appropriation. This type of appropriation, however, is merely an aspect of human labour, a material interchange between nature and human beings, which is necessary for their survival. Appropriation is also expressed in the concept of property, but one that is very much different from historically specific private property, which is distinctive of capitalist societies (see Hobsbawm 2011, 130; May 2010). As social animals, human beings develop both co-operation and social division of labour, the latter being nothing else than specialisation of functions, enabling people to produce a surplus over what is needed to maintain and reproduce the individual and the community. Furthermore, "the existence of both the surplus and the social division of labour makes possible exchange. But initially, both production and exchange have as their object merely use" (Hobsbawm 2011, 131). As human beings emancipate themselves from nature and start to "control" it (simultaneously also changing the relations of production), significant changes happen to the social relations into which they enter. A more detailed account of these changes will be looked at later and was partially already pointed out. In a historical sense, however, these changes are a result of both the aforementioned specialisation of labour, and furthermore, of the invention of the money form, and, with it, of the commodity production and market exchange. This provides "a basis for procedures unimaginable before, including capital accumulation" (Hobsbawm 2011, 131). In the latest phase, which occurred under capitalism, the worker was consequently reduced to nothing more than labour power. In the production process a total separation is made between use-value, exchange-value, and accumulation, which can be seen as a very distinct feature of this epoch. Reproduction is in fact separated from or even opposes - production (of commodities), where unity used to exist in the pre-capitalist social formations (Fortunati 1989, 8). The economic aims of capitalism, as one can see, are radically different from those of preceding modes of production that focused on the production of use-values in relation to the reproduction of human lives. For Fortunati, this means that commodity production can be posited as "the fundamental point of capitalist production, and the laws that govern it as the laws that characterise capitalism itself" (Fortunati 1989, 8). The main goal becomes an endless accumulation of still more capital, an accumulation for accumulation's sake - this rational intent to maximise accumulation is a "law" that governs all economic activity in capitalism (Wallerstein 1983).

It can be claimed that there is a whole complex of different categories, which need to be developed (producing a qualitative social change) to make capitalist society what it is: from abstract labour, commodity-form and commodification, which presuppose production with the sole intent of exchange (and consequently dominance of exchange-value) (see Marx 1990/1867, 733), to the expropriation of surplus-value in the production process, the social (and finally worldwide) division of labour, accumulation for accumulation's sake and also a historically novel possibility of an endless accumulation. And for the latter to be possible, accumulation of a capitalist presupposes valorisation, constant increasing of the value of the commodities bought, which is done through the production process (see Marx 1990/1867, 711). This complex also needs a specific capital relation and its reproduction, namely the capitalist on the one hand and the wage-labourer on the other (Marx 1990/1867, 724).

I will focus on these changes in more detail in the next (sub) sections. For a more detailed analysis of the historically specific capitalist epoch, as delineated by Marx, we are first bound to turn to the first volume of Capital (Marx 1990/1867). Looking at capitalism on its surface, one is quickly able to see there is an apparent rupture between the capitalist class and the proletariat, the latter being defined as those who do not own the means of production or are prevented direct access to (and thus divorced from) them. This crucial separation is constituted especially through the socalled primitive (or primary) accumulation, which can be seen as being an inherently extra-

\footnotetext{
${ }^{6}$ See also Barbalet (1983).
} 
economic process and thereby has little to do with how the economy is supposed to reproduce itself "normally". ${ }^{7}$ It is exactly primitive accumulation that historically and momentarily enables enclosures of the common lands, expropriation of the commoners, expulsion of peasants from their lands, incorporation of different activities and spheres into exchange relations, and finally, also incorporating these spheres into capitalist social relations (in the words of Sohn-Rethel, society of private appropriation in contrast to the previous societies of production). Amongst others - and one which is of indispensable importance for the existence of capitalist production - this process crucially contributes to the production of labour power as a commodity. It effectively prevents people from accessing the means of production and therefore also the means of their own subsistence, consequently pushing them into waged-labour (at the same time producing a very much changed constitution of society). Murdock $(2011,18-20)$ was one of the authors from the field of political economy of communication that constantly stressed the historical role of enclosures and processes of accumulation as dispossession for the march of commodification, which also forced people to start selling their labour power for a wage.

This factual inability to access the means of production is the key characteristic of the proletariat and its development in time contributes to ever larger proletarianisation of the labour force in capitalism as a historical system (see Wallerstein 1983, ch.1). As people are (often quite forcefully) rejected access to the means of production, they need to sell their labour-power on the labour market to survive, which is a historical novelty of capitalist societies (and took a long time to actually develop, initially pushing many people into extreme pauperism) (see Polanyi 2001/1944). People sell their labour-power on the market in a free and apparently fair exchange between the buyers (capitalists) and sellers (labourers) of this commodity. In most cases, this is in fact the only commodity proletarians own: their own body and capacities inherent in it, which can (or rather must) now be exchanged as a commodity on the market. The capitalist, as the buyer of the labour-power commodity, is only able to "hire" the labourer, or to be more precise, his capacity to labour, for a particular period of time ${ }^{8}$. The latter can be seen as one of the key tenets of both the liberal political economy and liberal take on human freedom in society. It enables both apparently free exchange between two consenting parties, which is carried out in the market, and development of the labour market itself. But as Marcuse pointed out, the fact that an individual is free to sell his labour-power is actually the prerequisite for labour-power to even become a commodity. The labour contract thus "epitomizes this freedom, equality and justice" (Marcuse 1955, 308) (and of course also necessity to be exploited) in the context of liberal capitalism. As Marx himself puts it, "labour-power can appear on the market as a commodity only if, and in so far as, its possessor, the individual whose labour-power it is, offers it for sale or sells it as a commodity. In order that its possessor may sell it as a commodity, he must have it at his disposal, he must be the free proprietor of his own labourcapacity, hence of his person". (Marx 1990/1867, 271) As the capitalist temporarily buys the labourer's labour power, he (or she) is able to employ him (or her) in the production process, where he (or she) can directly control him (or her), making sure the work he (or she) was hired for is done. Finally, in the production process, the labourer produces both (exchange-) value and surplus-value, the latter being the source of capitalist exploitation ${ }^{9}$.

\footnotetext{
${ }^{7}$ Primitive accumulation has (in most cases) been also an extremely violent process. There has been an increased interest into the problems of primary (or primitive) accumulation in recent years, demonstrating this is still a very much contested topic in the critique of political economy. It also demonstrates that this topic is gaining relevance in the existing historical epoch. One of the key arguments made in the reinterpretations of this concept has been that primitive accumulation is not a historically limited process, which would be significant only as a starting point of the capitalist accumulation. It is in fact constantly reproduced and therefore a permanent part of capitalism, helping both to constitute and expand capitalist social relations. On these issues see writings of Perelman (2000), Bonefeld (2001), De Angelis (2007, ch.10), Prodnik (2011), or Mezzadra (2011). Harvey $(2003,144-152)$ coined the term accumulation by dispossession to clearly denote permanence of this process in capitalist societies. On the privatization of the commons, which is connected to these same issues, see Bollier (2002) and Boyle (2008).

${ }^{8}$ It has not been stressed often enough, but individuals as such have no (exchange) value whatsoever in capitalist society and cannot have it. It is a commodity that is contained within the individual that potentially holds value: their capacity for production - labour-power. Capitalist therefore does not appropriate labourer as such, but his labour, and in concrete reality this exchange cannot happen in any other way but between the individual-as-capacity-for-production and capital (see Fortunati 1989).

${ }^{9}$ This can be seen as one of the key findings that Marx successfully proved in the first volume of Capital on an abstract level (Marx 1990/1867, 293-306): exchange between buyers and sellers of the labour-power commodity is, in fact, not fair. But not on the market, which is the surface of capitalist social order. This inequality develops in the production process, where labourer as a rule produces more value with his labour-power than he gets paid for: "The value of labour-power, and the value which that labour-power valorizes [verwertet] in the labour-process, are two entirely different magnitudes; and this difference was what the capitalist had in mind when he was purchasing the labour-power" (Ibid., 300). This is called surplusvalue and, in the first instance, it should be seen as a technical and not a moral term (as it is often both interpreted and used). Labour-power is also the only commodity from which more value can be extracted than it has been paid for in the market. According to Negri $(1991 / 1984,79)$, behind the appearance of exchange, a theft is thereby taking place. Further-
} 


\subsection{The exchange of Commodities and Social Totality}

This short summary might seem superfluous to those who are sufficiently acquainted with Marx, but it is crucial for the understanding of the roles that exchange, equivalence, and commodity have in his total argument. Products made in the capitalist production process are necessarily commodities. And they are also necessarily put into an exchange relation with other commodities, which can only be done through the market. This is, after all, what makes them commodities: their social character, their ability to be exchangeable because of their social desirability, and the market is the only way to compare these commodities. If this was not the case, they would be just some useful products for their actual producer, while the focus in the production process would simply be on the use-value of the products for their actual producer ${ }^{10}$. But the whole importance for the capitalist selling these products in fact lies in the production of exchange-value, which is, in most cases, expressed in the form of price on the market (i.e. through the money form, which is the universal equivalent and the measure of exchange-value). The ability to exchange these articles for the universal equivalent, which also makes extraction of surplus value fairly simple, is the sole reason the capitalist is employing labourers who produce these commodities. If something might be very useful for the society, but would at the same time (directly or indirectly) lack exchange-value, it, as a rule, could not be of any particular importance for the capitalists ${ }^{11}$. In the best-case scenario, it will be different support systems in the capitalist society (e.g. welfare state) that will take care of this or not.

Furthermore, because it is the capitalist class that sells products (commodities) on the market, it is incidentally (also) the labourer that needs to buy these products as the means of his subsistence. Doing so, he inadvertently assists with the reproduction of the capitalist accumulation cycle and capitalist system as a whole; the labourer consequently inadvertently perpetuates his own exploitation (see Marcuse 1955, 309; Hobsbawm 2011). The labourer thus unintentionally helps with the preservation of the existing class relations, because he is reaffirming labour's separation from the means of production. The working class (i.e. proletariat) is therefore integral to capitalism, its unavoidable part (Postone 2003/1993, cf. Marx 1990/1867, 716, 724), which is based on the property relation of private ownership of the means of production. What is of crucial importance here is that even though the history of modern society and capital is of course socially constituted, it nevertheless "possesses a quasi-autonomous developmental logic" (Postone 2003/1993, 31). How the capitalist system actually works is therefore more or less independent and automated, as it generates a dynamic that is beyond the control of any individual actor constituting it (but not necessarily of the coalition of subjectivities, multitude or a whole social class, which can collectively resist its domination, but these questions will not occupy us in the present text). This becomes especially clear when Marx talks about (exchange-) value, which is an "immaterial" appendage to the commodity. Even if it is immaterial, that does not make it subjective: it is both (socially) objective and at the

more, because labourer temporarily sold his labour-power to the capitalist before he entered the production process, the products he produced are alienated from him by the capitalist at the end of the working day (alienation is another concept that had vast influence in Marxism, but its conceptualization went through drastic changes even in Marx's own writings when his thought was developing). Final products of the labour process are therefore a property of the capitalist and not of its immediate producer, the labourer. Labourer waived away his right to the products when he temporarily sold his labourpower to the capitalist. Instead of retaining these products, he gets paid wages for his labour, which are of lower value than what he actually produced (hence, exploitation). The exchange between the worker and capital is therefore only formally an exchange of equivalents between equals. As Fortunati $(1989,9)$ points out, it is in fact an exchange of non-equivalents between unequals. The abstract argument made by Marx also presupposes that wage that labourer receives is no higher than living wages. He already came to this finding in 1847 , saying that "labour, being itself a commodity, is measured as such by the labour time needed to produce the labour-commodity. And what is needed to produce this labour-commodity? Just enough labour time to produce the objects indispensable to the constant maintenance of labour, that is, to keep the worker alive and in a condition to propagate his race" (Marx and Engels 1976, 125). Several authors claimed this was a nice example of how Marx was historically completely wrong. But they (perhaps intentionally) forgot this was an abstract argument, building on a rational tendency of how a capitalist will operate. There are, of course, several other tendencies and mechanisms at work in a concrete and complex social reality, amongst others political interventions made by the state (regulation of working hours, minimal wage), which are often a result of class antagonisms and power relations in a specific society.

${ }^{10}$ Again, it is exactly this social character that is the main characteristic of the commodity. The commodity must be exchanged on the market. It is paradoxical that a specific commodity would in fact not be a commodity, if it were a mere usevalue for its owner. "For its owner it is on the contrary a non-use-value", Marx (Marx and Engels 1987, 283) writes in the Critique. Commodity is "merely the physical depository of exchange-value, or simply a means of exchange. [...] The commodity is a use-value for its owner only so far as it is an exchange-value. The commodity therefore has still to become a use-value, in the first place a use-value for others". (ibid.)

${ }^{11}$ This is not because capitalist is somehow morally corrupt (even though he might be), but because in competitive market system he is pressured by the coercive laws of competition. If every individual capitalist did not follow his own selfinterest he would quickly go bankrupt. Capitalists therefore cannot set boundaries to their own activities in a competitive system. This is, for example, a very significant notion when ecological issues are debated. 
same time constantly changeable in space and time, because a commodity is a result of a socially useful (and also socially necessary) labour, which varies between specific types of society (e.g. because of rise and fall of productivity connected to technological developments, natural circumstances etc. $)^{12}$. As Marx puts it, "exchange-value appears to be something accidental and purely relative, and consequently an intrinsic value, i.e. an exchange-value that is inseparably connected with the commodity, inherent in it, seems a contradiction in terms" (Marx 1990/1867, 126). But as he develops his argument further, one can see that this is an argumentation distinctive of vulgar economics. The price of commodities indeed fluctuates, but neither value nor its market representation (via price and money) can be seen as arbitrary. Their common denominator is quantity of objectified (abstract) labour, put in the context of the whole capitalist economy. The labour time, "objectified in the use-values of commodities is both the substance that turns them into exchangevalues and therefore into commodities, and the standard by which the precise magnitude of their value is measured" (Marx and Engels 1987, 272). Nevertheless, labourers themselves have little actual influence regarding how much labour time is socially necessary to produce a certain commodity - it is market forces that govern these relations in the world of commodities - and neither do they, of course, necessarily enter into direct personal relations with other labourers in the market. All these relations appear as objective quantitative relations between commodities (usually represented via the money form) and only by looking behind this material veil is it possible to see that they are in fact antagonistic relations of production, where a conflict can emerge.

Marx's argumentation here is very complex and it can be argued that a coherently dialectical approach needs to be employed to sufficiently encompass it in its entirety. This would make it possible not to overlook any of the aspects of the capitalist order as a whole. What I have in mind here is a need to look at the social totality to adequately comprehend even the most abstract categories such as the commodity, value, or abstract labour. They are all constitutive cell parts of the system that influences and conditions them, meaning they cannot be adequately analysed when taken in isolation from one another or from the wider economic and social system. This need for totality is also one of the demands of dialectics; in this sense Marx's argument can be seen as a global and an all-encompassing one (see Lefebvre 1968; Harvey 1996, 48-57; Jameson 2009, ch.1; Harvey $2010,195 f$.). What seems important to note at this point is that looking at the commodity-form by itself would indeed be missing what it actually stands for: it is in fact an objective social relation. Not only does it make sense when it enters into exchange relations with other commodities and becomes a part of the world of commodities, thus presupposing a fully developed social division of labour ${ }^{13}$, other parts of the accumulation process also need to be taken into account: the circulation sphere, where exchange-value of these commodities is both realised and "measured" (it cannot be measured "directly" because, again, it needs to be put into a relation with other commodities; there is no way of knowing what the socially necessary labour time to produce a certain commodity is before they enter into this relation), while the sphere of production is where waged labour produces these commodities. As we are able to see, there is a certain societal structure that needs to be in place and functioning for a fully commodified society, where exchange of commodities takes place in a very automated fashion. In the words of Balibar: "The structure of production and circulation which confers an exchange-value on the products of labour [i.e. commodities] forms a single whole, and the existence of money, a 'developed' form of the general equivalent of commodities, is one of the necessary functions of that structure" (Balibar 2007, 61). All these categories and relations must be developed and functionally in place.

\subsection{Equivalence and the Real Abstraction}

The appearance of the commodity-form in pre-capitalist societies is essentially episodic. As Lukács $(1971,84)$ pointed out, this is when exchange-value does not yet have a form of its own and is directly bound to the use-value. The purpose of production in this context is to create use-values and they become means of exchange merely when supply exceeds the needs. It is only after the

\footnotetext{
${ }^{12}$ It is sensible to quote Marx here at length, because this is an important and often misunderstood presupposition: "The labour time expressed in and exchange-value is the labour time of an individual, but of an individual in no way differing [...] from all other individuals in so far as the perform equal labour; the labour time, therefore, which one person requires for the production of a given commodity is the necessary labour time which any other person would require to produce the same commodity. It is the labour time of an individual, his labour time, but only as labour time common to all; consequently it is quite immaterial whose individual labour time this is. This universal labour time finds its expression in a universal product, a universal equivalent [...] Only as such a universal magnitude does it represent a social magnitude. [...] The labour time of the individual is thus, in fact, the labour time required by society to produce a particular use-value, that is to satisfy a particular want" (Marx and Engels 1987, 272).

13 "But though it is correct to say that private exchange presupposes division of labour, it is wrong to maintain that division of labour presupposes private exchange" (Marx and Engels 1987, 299).
} 
commodity successfully penetrates society to the extent that it becomes dominant that the qualitative change occurs and the endless (capitalist) accumulation becomes possible. This is why, for Lukács, "the commodity can only be understood in its undistorted essence when it becomes the universal category of society as a whole" (Lukács 1971, 86). This development does not take place before the advent of modern capitalism, when (wo)man's own activity and labour become objective and fully independent of him (her) and his (her) wants, "something that controls him by virtue of an autonomy alien to man" (Lukács 1971, 87). The necessary abstraction of human labour is at this point incorporated in commodities and the process of abstraction in the economy is completed. While in the previous modes of production the aim was the production of use-values, which would serve the reproduction of the individual within specific communal relations, under capitalism the sole aim thus becomes "the production of exchange-values, i.e. the creation of value for value" (Fortunati 1989, 7). According to Fortunati, this leads directly "to the commodity, to exchangevalue, taking precedence over the-individual-as-use-value, despite the fact that the individual is still the only source of the creation of value" (Fortunati 1989, 7).

This development needs a specific kind of rationalisation, which, according to Lukács (1971, 88), is based on what is and can be calculated, so to say on instrumentally rationalistic measuring, which is the only way to enable equivalence (exchange-value) between factually unequal things (use-values). Sohn-Rethel $(1972,54)$ saw this as a type of mathematical reasoning, which can be traced also to the exchange abstraction (while he also connected it to objective knowledge and "exact" sciences). A consequence of this finding is that if the exchange process is to work effectively and reproduce itself in a society, it is obvious that a full-blown universalisation of equivalence needs to be carried out. A fully developed equivalence in fact has to be established between unequal things, making them measurable and thus comparable via some basic characteristic (in the case of Marx's labour theory of value these are abstract labour and labour time), if they are to be exchanged on the market. This leads us back to the cell-forms of capitalism, to the fundamental and most abstract categories in Marx's analysis, namely the commodity, abstract labour, and value, all being inherent parts of capital. All three categories are inexorable parts of capitalist societies in the most abstract sense.

It is quite clear that an abstraction is not only a thought process for social analysis, but is also a real, factual abstraction, "abstraction not by thought but by action and operating in time and space" (Sohn-Rethel 1972, 51). It is an abstraction developing through several fundamental categories: exchange abstraction, commodity abstraction, labour abstraction, time abstraction etc. (see SohnRethel 1972; 1978). As Marx points out, "equality in the full sense between different kinds of labour can be arrived at only if we abstract from their real inequality, if we reduce them to the characteristics they have in common, that of being the expenditure of human labour-power, of human labour in the abstract" (Marx 1990/1867, 166). This argument can of course be extended further on to other categories, beyond only abstract labour. According to Marcuse:

\begin{abstract}
"[Abstraction] is imposed upon the dialectical method by the structure of its subject matter, capitalist society. We may even say that the abstraction is capitalism's own work, and that the Marxian method only follows this process. Marx's analysis has shown that capitalist economy is built upon and perpetuated by the constant reduction of the concrete to the abstract labour. This economy step by step retreats from the concrete of human activity and needs, and achieves the integration of individual activities and needs only through complex of abstract relations in which individual work counts merely in so far as it represents socially necessary labor-time, and in which the relations among men appear as relations of things (commodities). The commodity world is a 'falsified' and 'mystified' world, and its critical analysis must first follow the abstractions which make up this world, and must then take its departure from these abstract relations in order to arrive at their real content. The second step is thus the abstraction from the abstraction, or the abandonment of a false concreteness, so that the true concreteness might be restored". (Marcuse 1955, 313)
\end{abstract}

This notion was further developed by some of the aforementioned authors, amongst others such as Sohn-Rethel, who points out that abstractness takes shape in different social institutions, primarily in that of money form. Sohn-Rethel also stresses that "at the time and place where it happens the abstraction passes unnoticed" (Sohn-Rethel 1972, 51-52), not least because in most cases transactions involve physical objects, while the commodity exchange is no less real than anything else; but abstraction still has a form of thought, even if it does not spring from thought, but from actual 
practical activities (check, for example, the abstraction developing in exchange process: no actual material change to the commodity happens, physical events are at absolute minimum, no quantitative differentiation to the exchanged commodity is allowed etc.; what changes is the social status of ownership of the commodity). The sole fact that abstraction passes unnoticed is perhaps the most important practical outcome of what develops in everyday life activities.

\title{
3.4. The Fetishism of the Commodity
}

Marx's notion of fetishism ${ }^{14}$ is a culmination of the processes mentioned in previous subchapters. His conceptualisation was fully expanded in the chapter Fetishism of commodities in the first volume of Capital (Marx 1990/1867, 163-177). Harvey believes the concept of fetishism is an "essential tool for unravelling the mysteries of capitalist political economy" (Harvey 2010, 38). Several fundamental arguments, which are crucial for this conceptualisation, have already been implicitly noted earlier in the text and one is able to see what an immensely complex issue this is. It is thus not surprising when Marx notes that fetishism is inseparable from the production of commodities, while commodity is full of "metaphysical subtleties and theological niceties", transcending sensuousness as soon as it emerges; it can be both a sensuous and a suprasensible or social thing (Marx 1990/1867, 163, 165).

As stressed by Jhally $(1983,29)$, there are two major reasons for how and why fetishism arises: firstly, because of exchange of commodities; and secondly, because of the relationship between capital and labour (or to be more precise, between capitalists as a social class and the proletariat), which centres around waged labour and is constitutive of wider capitalist social relations. Both of these reasons have been thoroughly analysed already.

Several critical communication scholars have dealt with commodity fetishism in their work (e.g. Jhally 1987; Maxwell 1991; Murdock 2006; 2011; Fuchs 2011, 152-154). Jhally wrote about fetishism:

\begin{abstract}
"In short, fetishism consists of seeing the meaning of things as an inherent part of their physical existence when in fact that meaning is created by their integration into a system of meaning. [...] For Marx, commodity fetishism consists of things seeming to have value inherent in them when in fact value is produced by humans: it is to naturalise a social process. Thus things appear to have value inherent in them. The essence however is that humans produce value. [...] It is quite clear that, for Marx, commodity fetishism and the mystery of the commodity concerns the false appearance of the commodity as possessing value in itself rather than as the result of labour. The theory of fetishism is indeed a theory of mystification." (Jhally $1987,29,39$ )
\end{abstract}

With universalisation of the commodity-form in society, production of commodities is performed by individuals or groups that labour independently of each other because of the social division of labour. This means that the inherently social relations of production are only manifested in exchange (Jhally 1987, 29, 39); but, as already stressed, these relations are in fact hidden behind a material veil, behind the commodity itself. This material veil not only hides the social relations, but also abstract labour, which produces commodities in the production process (which is the site of an antagonistic relation between the owners and the expropriated labourers. Murdock $(2011,19)$ believes it is a crucial characteristic of the fetishism that people (understood as consumers of commodities) forget where commodities came from, instead thinking these issues away and enjoying the convenience and pleasure these commodities are supposed to bring. The final effect is abolishment of any talk of exploitative working conditions, of the labour process or of the environmental degradation. All attention when buying commodities and consuming them is focused solely on the commodity as the object of pleasure.

Commodity fetishism is therefore a prime example of what is usually defined as ideology (see also subchapter Media and ideology by Fuchs $(2011,152-154)$, but it is an actually existing ideolo-

\footnotetext{
${ }^{14}$ Balibar $(2007,63)$ points out how Marx realized that the money (as the general equivalent or universal commodity that can be exchanged for any other commodity) fetish is in fact nothing else than commodity fetish. This was only possible with a careful analysis of the commodity form and the role of exchange-value in it, which was not present in Marx's earlier works. In these earlier works this particular social role, which he later ascribes to commodity, is in fact often attributed directly to money: "The complete domination of the estranged thing over man has become evident in money, which is completely indifferent both to the nature of the material, i.e., to the specific nature of the private property, and to the personality o the property owner. What was the domination of person over person is not the general domination of thing over the person, of the product over the producer. Just as the concept of the equivalent, the value, already implied the alienation of private property, so money is the sensuous, even objective existence of this alienation" (Marx and Engels 1975, 221).
} 
gy that cannot simply be ignored or thought away, not an illusion. Commodity fetishism has an objective reality that is inevitable in capitalist societies, because it attaches itself to the commodity in the moment it is produced (Marx 1990/1867, 165). This is so, especially in the present context of the world division of labour and the global market. This material fetishistic construct veils what is in fact happening behind the market: specific social relations of labour exploitation. The aforementioned difference between appearance (the world of commodities) and essence (social relations of production) develops here in its entirety. It is thus especially through the fetish character of commodities that Marx's claim of the power of abstraction and dialectics is able to demonstrate its strength: He claimed their crucial characteristic is an ability to go beyond mere appearances of things.

An important consequence of commodity fetishism is that commodities thus exist independently of human beings, of those that in fact produce them, and assume a life of their own. But not only do they acquire independence from human beings, they become active and objective agents of their oppression (see Marx 1990/1867, 175; Barbalet 1983; Postone 2003/1993). As Harvey stresses, it is "market forces, which none of us individually control, [that] regulate us" in capitalist society. (Harvey 2010,42$)$

The issue of commodity fetishism is in fact an "alternative" approach to the enduring problem of ideology. At least two diverging (to an extent, even conflicting) strands of critical analysis of ideology have developed in twentieth century Marxism. One is taking as a starting point commodity fetishism, taking commodity-form as an actually existing material veil that develops at the material level (in the base-superstructure model of society schemata) and amongst others includes theoreticians such as Lukács, Adorno, Sohn-Rethel or Postone (some of these authors developing from this point of departure concepts like reification or alienation). In critical communication studies such an approach to the base-superstructure formula has been taken especially by Smythe (1977; see Meehan 1993) and the authors participating in the audience commodity debate. In the other strand, in which one could include, for example Althusser or Žižek, the focus has been almost solely on the ideological level and apparatuses that produce ideology. It presides and develops through the level of superstructure, while being determined by the base, but in a different sense of the ownership of the means of production (i.e. the class in power is able to define ideology at the level of superstructure). Let us remember, Marx (see Marx and Engels 1987, 263) includes in the superstructure "the legal, political, religious, artistic or philosophic - in short, ideological forms" of life. Even though there is a relational approach between base and superstructure, in the latter approach, it is very much different from the former and leaves out questions concerning commodity fetishism. While for the latter ideology, it is solely a question of superstructure, the former sees ideology as the material veil produced by exchange of commodities; it is therefore a constitutive part of the material base from which it emerges (it can thus be seen as an immanent approach).

It is not the purpose of this paper to present a detailed overview of these two approaches, but the former approach seems much closer, for example to Williams' (1973) reinterpretation of base and superstructure models or to Gramscian's (1971) concept of hegemony, which offers a viable alternative to the concept of ideology (both are close to Fuchs's $(2011,48-53)$ reconsideration of base and superstructure). In a Gramscian sense, one could claim that commodity fetishism is reproduced through everyday activities of human beings whether they want to or not, but it also demonstrates how the base is far from being static and without conflicts ${ }^{15}$. This approach largely encompasses material base, so to say production forces, production relations and conflicts and antagonisms emerging from this level of society. This is so, because the base is a precondition of the superstructure and also more fundamental than superstructure (to a large extent, base also restricts how superstructure functions, but it cannot determine it). This material level therefore in a significant sense forms and influences consciousness at the level of superstructure, which arises on this "real foundation", the material base; this seems to be much closer to what Marx himself claimed is actually happening in society, at least in comparison to where Althusser puts his focus. In his famous definition, given in the preface of $A$ Contribution to the Critique of Political Economy, Marx points out that "the mode of production of material life conditions the general process of social, political and intellectual life", and furthermore, "it is not the consciousness of men that determines their existence, but their social existence that determines their consciousness" (Marx and Engels 1987, 263).

Significantly, Sohn-Rethel's goal is precisely to research this relationship between base and superstructure and to build a staircase between "productive forces and production relations which together form the material basis for consciousness as superstructure [...] The staircase must be

\footnotetext{
${ }^{15}$ This was most forcefully pointed out by Williams (1973) in his critique of mechanistic interpretations of the (often contradictory) relation between base and superstructure.
} 
given a firm anchorage in the basement, and this, for commodity-producing societies, can only be found in the formal analysis of commodity itself" (Sohn-Rethel 1978, xi). For the former approach, it is the material veil that is crucial to understand mystification in society and this material veil in fact exists (it cannot not exist in capitalist societies, not least because social relations can never be direct, unmediated (see Postone 2003/1993, 167)). It is obvious that people might become conscious of class antagonisms at the level of ideology and fight out this conflict by overtaking apparatuses in the superstructure, but this might not change much if some of the basic categories at the material level stay the same (for example dominance of the commodity-form and private ownership of the means of production). This is also significant in the context of the really existing socialisms.

\subsection{Exchange as the Key Agent of Individualisation}

Even though Marx's fundamental ontological position was that human beings were social animals $^{16}$, he was not naïve. In his time, a full-blown individualisation already took place and he acknowledged this was a society of free competition, where individuals seem detached from the natural bonds and are emancipated from nature (in words, "the dissolution of the bondage relations which fetter the worker to land and soil and to the lord of land and soil" (Marx's 1993/1858, 502)). Social relations already changed significantly and individuals were largely independent from each other, at least in comparison to the earlier historical periods, when they were a part of a definite and limited human conglomerate (Marx's 1993/1858, 83-85; see also Barbalet 1983, ch.3).

However, according to Marx, individualisation was not a natural condition of human beings emerging from their human nature, which seemed to be a predominant philosophical position since the seventeenth century. It was a result of a definite historical process. According to him, a human being is, paradoxically, "an animal which can individuate itself only in the midst of society. Production by an isolated individual outside society [...] is as much of an absurdity as is the development of language without individuals living together and talking to each other" (Ibid., 84). For Hobsbawm, "this process of the emancipation of man from his original natural conditions of production" can thus be seen as "one of human individualisation", exchange being one of its crucial agents (Hobsbawm 2010, 132). Human beings can thereby individualise themselves only through the process of history and this is a self-reinforcing process.

As demonstrated by Barbalet (1983, 69f.; 89f.), Marx's claim in his earlier writings was that relations of human beings in capitalist societies were in fact unsocial; he claimed that in the capitalist epoch, they become external relations of independent and unsocial beings (which was a presupposition that was not far from that of liberal individualism $)^{17}$. When Marx's thought developed further, however, he changed his opinion, stating these relations "are merely a particular form of social relation, different in content from the relations of feudal society" (Barbalet 1983, 89). The capitalist historical epoch can in fact be seen as still having the most highly developed social relations, especially because of the nature of exchange and the role commodity plays in society (as mentioned earlier). It does however produce spatial rather than direct relations, while also functioning completely beyond the will or control of actors themselves (Barbalet 1983, 90f.).

Commodity transactions of course carry no particular social or reciprocal obligations, as was the case with preceding divergent types of moral economies that were dominant before the rise of political economy (see Thompson 1991, ch.4; ch.5; Murdock 2011). Crucially then, the commodity-form is "not only the basis of individualised society, it is also the root of the view that the individual is without social relations" (Barbalet 1983, 92), a predominant ontological presupposition especially in liberal, libertarian and other individualist outlooks on the world.

\section{The Global Commodification of Everything: The Long History}

The capitalist system can only have one objective when operating, i.e. to accumulate capital (and even more capital). This is done by the holders of capital. A specific type of society with certain relations between people had to be established for this to be possible. Even though capitalism has

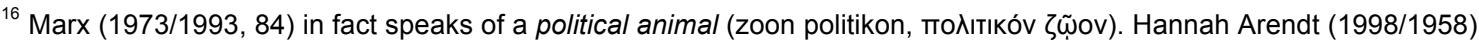
was correct when she pointed out that Marx in fact conflated social with political realm, reducing Aristotles's notion of zoon politikon simply to social animal (for Arendt, there was a complete victory of society over political realm and public action in modern societies). Even though differences between these two conceptualizations are important, they are not central for this text.

${ }^{17}$ In his Comments on James Mill Marx $(1975,220)$ for example claims that "the greater and the more developed the social power appears to be within the private property relationship, the more egoistic, asocial and estranged from his own nature does man become. Just as the mutual exchange of the products of human activity appears as barter, as trade, so the mutual completion and exchange of the activity itself appears as division of labour, which turns man as far as possible into an abstract being, a machine tool, etc., and transforms him into a spiritual and physical monster".
} 
been naturalised and one usually finds it difficult to think of alternatives, especially as this system has been fully embedded for so long, its development was difficult and full of obstacles ${ }^{18}$. In his attempt to explain why capitalism emerged as a social system, Wallerstein $(1983,40)$ writes that it is not so easy to provide answers to this question, as it might seem at first. Far from being a natural system, as its apologists claim, it is in fact a patently absurd one: "One accumulates capital in order to accumulate more capital. Capitalists are like white mice on a treadmill, running ever faster in order to run still faster" (Wallerstein 1983, 40). As he stresses (Wallerstein 1983, 15), the whole circuit of capital was only seldom completed before modern times; several links were missing, meaning several processes were not yet transacted through the market, which means they were not yet commodified. For Wallerstein (1983, ch.1), historical capitalism thus, first and foremost, presents itself as a process of a widespread commodification of different social processes, with it forming complex commodity chains (that in time become global). It is not merely a question of exchange processes, but also of commodification of production, distribution, and investment processes $^{19}$.

As Jameson (2011) lately pointed out, commodity is not only a prerequisite to capitalist processes of accumulation, it actually constitutes "pre-history" of capital and is therefore strictly speaking "not yet about capital". Even though Jameson's contribution is an important one, this statement seems at least partially problematic. The commodity-form is not only an enduring prerequisite of capitalist accumulation, but also its ever-present and constitutive part (similarly to primitive accumulation), which on the most fundamental level enables extraction of surplus value. Looking at the process of capitalist accumulation from a dialectical point of view, which Jameson himself strongly supports, it is impossible to separate the commodity from exchange and surplus value (historically speaking, they ought to develop simultaneously). The commodity-form is a crucial cell-form in every sphere of the cycle of capital accumulation (for a good overview of the expanded reproduction of capital and cycle of capitalist accumulation see Fuchs's overview (2011, 137-141)) and even though the production process, for example, might seem primary, capitalism cannot exist without reproducing itself via commodification, which enables its further expansion, and without commodity-form as one of its integral parts.

Whether one agrees with him on the mentioned issue or not, Jameson also acknowledges that in a social period, which is dominated by commodification, this process plays a crucial political role for an enduring critique of existing society. While Murdock (2006) wrote about the commodification of almost everything, both Wallerstein and Jameson went further, stating it is in fact everything that can be commodified. According to Jameson $(2011,16,26)$, in a capitalist society, commodification becomes tendentially universal and one can speak of the tendential dominion of the commodityform. Similarly, Wallerstein points out that "the process of global accumulation is developing via the commodification of everything" (Wallerstein 2001/1991, 24f.).

Murdock explains how "only in a fully developed capitalist system is the production and marketing of commodities the central driving force of growth and profit" (Murdock 2011, 18). The world market is thereby a crucial development in capitalism (Hobsbawm 2011, 145) and we can claim that in the last decades it finally developed in its entirety, constructing a universalised totality where everything can become subsumed under the rule of capital (Hardt and Negri 2001). Processes of commodification are crucial for this expansion of capitalism together with primitive accumulation (or accumulation as dispossession). This constant expansion is also one of its unavoidable necessities, because without constant expansion, a capitalist system is in crisis. It is thus fair to say that commodification is reshaping the world in its own image. This led Huws to state that this process can be seen as central in understanding social changes. With commodification, she has in mind "the tendency of capitalist economies to generate new and increasingly standardised products for

\footnotetext{
${ }^{18}$ Wallerstein $(1983,18)$ writes how an endless accumulation of capital has been the sole objective that prevailed in economic activities, but as penetration of these processes entered the social fabric, so did the opposition to these processes grow greater and louder.

${ }^{19}$ It might be appropriate to distinguish between commercialization, commodification and objectification, three processes that are, as pointed out by Mosco $(2009,132 f$.), usually associated. Commercialization could also be called marketization and it is the narrowest of the three processes. It refers to what is happening on the surface of the capitalist economy, so to say, on the transparently visible market: in the exchange process, the sphere of circulation. In communication studies commercialization/marketization would for example refer to the relationship created between audiences and advertisers (ibid.). Capitalist market necessarily encompasses a lot more that just exchange relations of this kind; as already pointed out, it for example presupposes commodification of labour that produces commodities and should therefore also encompass the production process. In this sense commodification, which is the main focus of political economy of communication, is a much broader notion. Lastly, objectification refers especially to specific process of dehumanisation. Lukács (ibid.; 1971) for example used the word reification to denote how human beings and personal relations become thing-like (ibid.). Not everything that is objectified is necessarily a commodity of course.
} 
sale in the market whose sale will generate profits that increase in proportion to the scale of production" (Huws 2003, 17).

As stressed by Polanyi (2001/1944, ch.6), there is, however, also a constant need for commodity fiction to legitimise the selling of different types of commodities on the market, which can serve as a constant reminder of the extreme artificiality of the capitalist market economy. This is especially obvious when market relations in certain spheres are still in the process of being established and have not been subordinated to commodity exchange beforehand. The great transformation from a feudalist to a capitalist society, as Polanyi called it, required new fictitious commodities for the successful functioning of new economic relations, most evidently labour force, money, and land. In an ongoing transformation to postmodernity, one can, on the other hand, establish that we are experiencing a historical epoch that is increasingly void of non-commodified products, processes, or activities, which can all be willy-nilly subsumed and subdued under economistic rationalisation. ${ }^{20}$ In their chapter on culture industry, Horkheimer and Adorno (2002/1947, ch.4) anticipated such a development of capitalist societies, pointing at the commodifying processes taking place. But even their analysis could hardly be ascribed with the prediction that capital will be able to colonise almost all spheres of society, meaning that nearly all aspects of human life can be comprehended as a possible investment or a market opportunity. Capitalism has therefore not incorporated only cultural production, public places and creativity, or, more widely speaking, social symbols, into its accumulation cycle. At first, it really made an industry out of culture and human artistic creativity (Adorno 2001/1991; Horkheimer and Adorno 2002/1947, ch.4). But in time, it was not only symbols, public expression and ideas that were (as today) constantly being commodified, but also knowledge and information as such, while both categories are becoming an integral part of capitalism in postmodern societies (see Schiller 1989, Parker 1994, Fleissner 2009, May 2010). And as Marazzi (2008) points out, information and communication are not only raw materials, but also a labour instrument (cf. Williams 2005/1980, ch.2). Information and knowledge became commodities as any other, bought and sold, producing aggregation of resources in the cultural and information sphere. Herbert Schiller called this the consciousness industry, while indicating "the entrance of the profit motive into fields, which for different reasons, historically had escaped this now pervasive force" (Schiller 1989, 91). Entirely new private industries have been developed and, in most cases, these same industries are exerting vast influence on how we think and act in our everyday lives (see also Jhally 1987, Hardt 2004). These privatisation and commodification processes on the other hand also constitute new monopolies of knowledge that have historically been typical of all human societies (see Innis, 2008/1951).

Debord's (1978, ch.2) account of the role played by commodity-form in postmodern societies, fully submerged in the spectacle, remains one of the most powerful accounts of the world, in which we live, ever written. He touches on the domination of the commodity over the totality of human living and presents spectacle as a permanent opium war, which feeds itself in, and through, the world of commodities. Everything is incorporated into the world market and changed in the way it satisfies the rules made by the capitalist type of economy and its instrumental rationalisation. Because commodity is independent of anything, it can autonomously rule over both the entire economy and society; social life thereby becomes completely colonised. The spectacle is, for Debord in fact "the moment when the commodity has attained the total occupation of social life. The relation to the commodity is not only visible, but one no longer sees anything but it: the world one sees is its world". (Debord's 1978, ch.2, par.42) Everything is submerged in the spectacle and the complete rule of the world of commodities fulfils itself through the spectacle. Debord's focus was at least indirectly pointed towards the mass media and a society flushed with images - and it is only after decades that most theoreticians admit that we live in fully mediatised societies. To put it in Debord's words, yet again, we have to recognise in these symptoms "our old enemy: the commodity". (Debord's 1978, ch.2, par.35)

It is quite possible that Debord's critique of contemporary life was (perhaps even rightly so) seen as an exaggeration when it was written almost five decades ago. But most of Debord's observations look increasingly obvious in the fully developed postmodern society where human sociability, affects and communication as such are transformed into commodities and exchanged. This expansion of commodification to communication therefore also means that these issues must be-

\footnotetext{
${ }^{20}$ What Polanyi failed to notice was that it was not only land, labour, and money that were fictitious commodities. All commodities are fictitious. There is no such thing as a "natural" commodity. The simple difference is that some commodities quite obviously need some sort of an ideological underpinning (or an underlying fiction) to socially legitimize them as commodities that are bought and sold, while commodity-status of others is rarely questioned, especially when they are already successfully legitimized as commodities in a specific society.
} 
come central topics of the political economy of communication, which simultaneously also needs to widen its scope of inquiry as much as possible and provide a critique of these invasive processes.

\section{The Political Economy of Communication and the Audience Commodity Thesis}

Global expansion of capital into previously non-commodified spheres indicates that political economy of communication in many ways started to overlap with inquiries made by other fields originating in the critical theory of society. The critical (e.g. neo-Marxist) approach to political economy (and critical theory of society more generally) has of course been regarded as essential for media and communication research from its beginnings. Even though Smythe (1960) is usually considered as the founder of the political economy of communication, deeper origins of the critical approach toward media and communication can be found much earlier; at least as early as in Adorno and Horkheimer (2002/1947; Adorno 2001/1991) on the one hand, or Innis (2008/1951) on the other. Both cultural studies and political economy in fact shared similar origins that can be derived from these authors, while also sharing basic agreement regarding the critical analysis of capitalism and the cultural processes therein (see Babe 2009, ch.1; Wasko 2005, 42f.). The increasingly important role of communication in postmodern societies produced several new convergence points between critical theory and the political economy of communication (e.g. Fuchs 2010).

Focusing on how the commodification process is considered in the political economy of communication, we can see that there are at least two general aspects significant for this relationship (Mosco 2009, 12f., 130). On the one hand, both communication and technology support commodification processes in the economy and throughout society. The role of technology in instrumental rationalisation that is necessary for commodification is becoming particularly transparent with digitalisation. On the other hand, however, commodification also penetrates institutions related to communication and starts to encroach on everyday social practices that have their foundations in communication. Both aspects are also stressed by Fuchs, who gives a close reading of Marx's thoughts on communication and media (Fuchs 2011, ch.4). According to Fuchs, Marx establishes that communication media are, on the most basic level, important in co-ordinating production across distances, accelerating transmission of messages and co-ordinating the transport of commodities between different establishments. They are furthermore crucial also in a more fundamental sense, helping to widen the expansion of capital into non-commodified spheres where accumulation and consumption could be developed (but were not yet). This process therefore supports the whole circulation process of capital. Mosco (2009, ch.8) terms this process "spatialization", which denotes overcoming of the constraints of space. As we are able to see, the spatialisation process is directly connected to commodification. In a more narrow sense of the media infrastructure and media contents, Fuchs also points out that for Marx, transmission technologies are operated by corporations. This means not only that the media themselves are commodities (and so is the infrastructure), but they consequently also transmit commodities. Media can be seen "as carriers of advertising messages that advance commodity sales" (Mosco 2009, 149), consequently accelerating the circulation of commodities.

Two other categories crucial for the political economy of communication and critical communication studies have been labour and audiences. As noted earlier in the text, selling labour power on the labour market is one of many important preconditions of the capitalist economy. A significant novelty is that in the information society, knowledge and information became fully commodified, which created a need for new types of labour that would be able to satisfy this "social" need. In the political economy of communication, labour has thus been analysed especially in its varying communicative-forms (as knowledge labour, information labour, labour of journalists etc.) and most of the work was done by Mosco and McKercher (2008). However, my focus in the text will be especially on the second category, audiences. Their commodification is also a relative novelty in the capitalist economy, while the conceptualisation of audiences as commodities raises several important questions regarding the pervasiveness of commodification in society.

\subsection{Audiences in the (Critique of the) Political Economy of Communication}

The critical political-economic approach toward audiences is a heterodox and alternative approach that is in most cases overlooked in mainstream and celebratory communication studies focusing on this topic ${ }^{21}$. This is so despite the fact that the so-called "blind spot debate" was one of the most

\footnotetext{
${ }^{21}$ Perhaps most striking is the fact that "representative" literature neglects critique of political economy when it comes to audiences. A four-volume collection on audiences released by Sage in 2009, entitled Media Audiences, offers no valuable
} 
heated debates in the historical development of the political economy of communication and provided several useful insights that seem crucial in understanding how audiences are instrumentalised by capital. This long-lasting debate, which at least indirectly continues in a much different technological and social context of today's society (see Bermejo 2009; Napoli 2010; Fuchs 2010; Caraway 2011; Biltereyst and Meers 2011; Kang and McAllister 2011), is an invaluable source for practices and ideas connected to Marxian-inspired critical communication studies. Perhaps even more importantly, it also provides several insights into how commodification spreads throughout the social fabric and how we are able to analyse these processes in postmodern society, which is completely permeated with communication. Insights provided by (the critique of) political economy in communication studies can thus offer a wide reflection on the current historical epoch by going beyond narrow affirmative approaches.

With the "blind spot debate", the issue of commodification in the media and communication has been extended beyond content and media labour to audiences. Audiences became the key media "goods" towards which scholarly attention could and should be aimed. Before this debate, media content has commonly been viewed as the vital commodity sold by the media to its readership. The recognition that "the mass media are first and foremost industrial and commercial organisations which produce and distribute commodities" (Murdoch and Golding 1973, 205f.), has already been widely accepted amongst critically engaged theorists. This important rethinking of the role of critical communication studies was initiated by Smythe $(1977)$. Both Mosco $(2009,12)$ and Meehan $(1993)$ have pointed out that Smythe's article, in which the audience commodity thesis was first proposed, has produced a fundamental shift in critical communication research. It could now include in its scope all communication companies that advertise, not only the media themselves. This can in fact be interpreted as an early and radical widening of the possible areas for analysis that can be carried out by the political economy of communication and this scope was, furthermore, extended by Smythe's belief that political economy can, in its widest meaning, be defined as "the study of control and survival in social life" (Mosco 2009, 3). According to this interpretation, political economy can be seen as the most holistic, and all-encompassing approach, while in many ways resembling the critical role it should in fact provide in its analysis of society.

In many ways Smythe's findings almost prophetically predicted some of the topics that would later become important in the framework of changes concerning immaterial work and post-Fordist production, which are well demonstrated by Gorz (2010) (in this text they are dealt with in Section 5). It is thus of the utmost importance to assess some of Smythe's key provocative statements and their continuing (in)validity in light of the rise of new media technologies, especially the Internet.

\subsection{Smythe's Audience Commodity Thesis and Technological Changes}

It is possible to derive a few key theses from Smythe's (1977) original article that initiated the audience commodity debate. His theses are not only still pertinent, they have been in fact reinforced by the technological and social changes ever since they were first proposed ${ }^{22}$.

insights from the political-economic point of view, even though it contains many texts on this topic, encompassing 1320 pages (see: www.uk.sagepub.com/books/Book233064). The same, for example, holds true for the journal Participations: International Journal of Audience Research, now renamed into Participations: Journal of Audience \& Reception Studies, that "welcomes contributions from different fields", like "sociology, psychology, anthropology, linguistics, folkloristics, cultural and media studies" (see: www.participations.org). As it can be seen, the journal states basically every possible approach, perspective, and discipline, one of the rare exceptions being political economy. The same thing can be observed in respect to the recently published Handbook of Media Audiences, edited by Virginia Nightingale (2011), which almost completely avoids political economy (with perhaps an exception of Napoli's contribution) and only by a mere coincidence (if at all) touches at questions such as power relations, private ownership, exploitation, or class relations. Political economy, and especially its critique, is often neglected and concealed when it comes to audiences; they are often seen as proactive and empowered "consumer-citizens". Little to none reflection is given to the vast discrepancies between the owners of the means of production and the "consumers". This means questions concerning wider structural issues and social totality are quite possibly completely overlooked and taken for granted. To state it differently: in these approaches, capitalism is something that stays in the background as an irrelevant or presupposed factor, its influence not being worthy of any deeper analysis. When Marx and critique of political economy are used, they are often seen as outdated and reductionist or even deliberately misinterpreted (I thank the reviewer of this paper for his comments on this issue, see also the critique provided by Biltereyst and Meers 2011). This is for example quite obvious in Fiske's influential book Introduction to communication studies (1990), which describes Marx's theory as "economistic". It also reduces it to the issues concerning ideology and gives very simplistic accounts of complex Marxist arguments.

${ }^{22}$ One of the initial claims by Smythe (1977) was that critical theory, for example Western Marxism, had more or less ignored communication (hence "the blindspot"). One could claim so forty years ago, but it is hardly the case today. And it was a problematic thesis even then (both in the case of Austro-Marxism and some of the authors working in SFR Yugoslavia), which Murdock (1978) sufficiently pointed out in his reply to Smythe. Nowadays we have a developed field of study in political economy of communication, while some of the radical neo-Marxist positions, for example autonomism, presuppose it is basically communication that is the main category in post-Fordist capitalism. 
Firstly, audiences are crucial commodities, which are manufactured and sold on the market. And not only this, audiences in fact labour! These were the main starting-points of the debate on the "audience as commodity". Smythe argued that the most important commodity produced by the media industry is the audience itself, which is constructed and then sold to the advertisers. This thesis not only survived the test of time, but has escalated in importance since it was proposed, which is demonstrated by several other critical approaches dealing with similar issues (one of them is dealt with in chapter 5). This seems especially interesting because when Smythe wrote the article, his notion of audiences as commodities was often dismissed as a return to vulgar Marxism and he was accused of reductionist economism by his critics (Meehan 1993). The resurrection of the idea of media as a business, bound by the logic of profitability, even seemed old-fashioned at the time when Cultural Studies reigned supreme. In the early nineties, Meehan (1993) argued that Smythe could have in fact even been more radical in his analysis and subsequent claims. According to her, the validity of the theses he proposed were proven to be completely correct by history and actual practice ${ }^{23}$. Indeed, according to Biltereyst and Meers (2011), who recently took a fresh look at this debate, media content becomes secondary, a free lunch at best. Media in fact first and foremost produces audiences, not programmes or content! This means media as tendency become mere hunter-gatherers of the audience, while leisure time becomes an increasingly important component of capitalism, which is able to expand and commodify previously unknown territories. What is comprehended as leisure time, non-work time, is subsumed under capital, monetised and valorised.

Interestingly, Adorno (2001/1991, ch.8) indicated these processes as already happening in the year 1969, when the essay Free time [Freizeit] was published. He states that free time is becoming its own opposite, a parody of itself, because it is only a continuation of profit-oriented life; it becomes subjugated to similar norms and unfreedom distinctive of the production process. $\mathrm{He}$ demonstrates this through the hobby ideology. Everyone must have a hobby now, possibly one that can be supplied by the "show business" or "leisure industry" (both terms losing all of their irony). Free time is thus subject to much social control. It was therefore only a matter of time, before all of the living time became commodified in its entirety. Similarly to Adorno, Williams (2005/1980) pointed out a decade later how the means of communication must be seen as a means of production, and this is especially so in modern societies, where communication significantly develops and becomes an important (both direct and indirect) productive force.

Secondly, an even more important and radical thesis was derived by Smythe on the basis of these initial findings. As if he simply continued Adorno's and Williams' line of thought, he claimed that today, "work time for most people is twenty-four hours a day" (Smythe 1981a, 121). Consequences of these findings are radical and wide-ranging and even more importantly, Smythe's observations are proven day-by-day. Even if one disagrees with Smythe's observation of how labour should be defined, which is indeed a complex issue, his thesis in its fundamental demonstrates the radical expansion of commodification throughout new spheres of society.

Both of Smythe's theses suggest that what can be considered as labour time has been radically extended into non-work time, when labour power is usually reproduced. Jhally and Livant (in Jhally 1987, 83-90) extended this notion further, while firmly basing their view in the critique of political economy as outlined by Marx. They pointed out that watching (as a form of labour) is in fact just an extension of factory labour and this should not be seen as a metaphor. It is a specific form of labour that is vital in the whole media economics process; similarly to how labourers sell their labour power to capitalists, so audiences sell their watching power to media owners. Leisure thereby becomes an increasingly important component in the workings of contemporary capitalism; it is subsumed under capital, monetised, and valorised, while audiences are viewed instrumentally, with the sole goal of (surplus) value extraction. Activities of audiences (listening, watching, browsing, "clicking") produce value, which is appropriated by the capitalist, which in exchange offer an apparently free lunch (various types of content).

Smythe's theses, as already pointed out, also indicate that all aspects of social and individual human life can be fully commodified and be drawn into the capitalist accumulation cycle, whether one wants and knows this or (preferably) not. There are basically no human activities left, from which a certain magnitude of exchange value could not be extracted and appropriated. This is possible also because of the rise of digital technologies that started to play a crucial role in these very processes, providing unprecedented detail and further rationalisation of measuring, quantification, and control (see Napoli 2010; 2011). Napoli $(2011,10)$ even goes as far as to claim that a broad array of options for data gathering, which the media corporations are able to use today, make the

\footnotetext{
${ }^{23}$ It is the contradictory (almost antagonistic) three-folded relationship between audiences (living beings that are again being reduced to commodities), content in the media, and advertisers (representing capital), that is crucial here.
} 
Internet almost too measurable. These techniques make it possible to record an unprecedented level of detail of its users (or in the discourse of marketers: individual consumers). In this sense, Castells's notion that the Internet is the fabric of our lives, could hardly be taken more seriously, when it comes to the encroachment upon people's privacy.

The key changes brought by new digital technologies that offer new ways of controlling and measuring the audiences are: a) fragmentation; b) formally increased autonomy, participation and engagement of audiences; c) unprecedented control over consumption; and d) unprecedented detail of measuring users and audiences (Napoli 2011). Fragmentation of the media environment and consequently audiences brings an increasing prominence of the "Iong tail" scenarios, which break audiences into smaller and smaller pieces. There is a historical development from broadcasting, distinctive of the early mass media, to "narrowcasting", which was enabled by satellite TV and infrastructure privatisation and deregulation, and finally to "pointcasting", which is made possible by digitalisation and the Internet. The latter enables a radical "rationalisation of measuring" and full quantification of every activity that potentially becomes monetisable through several different techniques and methods (e.g. via data mining, see Gandy 2012, Andrejevic 2012, Fuchs et al 2012, Prodnik 2012). It is true that Internet users (also called "cybernauts") can be more engaged and have more influence over how they use the new media than before, but from the perspective of the political economy of the Internet, this enables the owner of the platform they are using an even more detailed measurement of their activities and preferences, possibly also their social status and other personal information. It is an idealist notion to speculate blindly on the revolutionary possibilities that have supposedly been opened up by the Internet. A more materialist approach should take into account the wider social context and recognise that the asymmetries have been growing in the last couple of decades and the Internet unfortunately did little to mitigate this. On the contrary, it could even be claimed that digitalisation to some extent helped to widen these gaps and intensify concentration and discrepancies between those in power and the disempowered many (see Hindman 2009, Bellamy Foster and McChesney 2011).

An exemplary case of the mentioned characteristics is, without any doubt, Google (see Kang and McAllister 2011). This corporation derives most of its profit from advertising (especially its main advertising product Google AdWords), by extensively commodifying its users, fragmenting them into niche audiences and then selling them to prospective advertisers that offer specific types of commodity that relate to these audiences. One of the theses, regarding the post-Fordist economy, proposed by Marazzi (2008), points precisely at such key duties of corporations: differentiation of products becomes one of the ways of getting the attention of the consumers. Production, in this light, steps into the background, at least to a certain extent, while the previously less noteworthy attention economy increases in importance. In fact, Google's yearly profit is levelled with annual budgets of some smaller nation-states (e.g. Slovenia, with a population of 2 million people), while (formally!) employing 30000 people. This is only possible by severe infringement into the privacy of the users, a process in most cases denoted as economic surveillance (see Fuchs et al 2012; Prodnik 2012). Several authors, amongst them Pasquinelli (2009) and Fuchs (2012), point out that one of the most important sources in the process of capital accumulation by Google is the unpaid labour of the people using its platform, with the World Wide Web content-producers being the other. Both can consequently be exploited, because Google Corporation is able to extract surplus value from their activity. This brings us directly to the definitions of the social factory and general intellect provided by the autonomia (post-operaist) movement, which are discussed in Section 6.

\subsection{Caraway's Critique of Smythe and the Subject Matter of Political Economy}

One of the more forceful recent critiques of Smythe's findings came from Caraway (2011), who quite vigorously argued against several of the basic presuppositions which Smythe put forward in his seminal study. While his critique is in no way representative for a quite long series of different rebuttals - they came especially from the field of Cultural Studies and were often directed against political economy in general (for an overview see Biltereyst and Meers 2011, especially 417-424) it does offer a fruitful ground in the context of this text. This is especially so, because Caraway claims he is giving a Marxian revisiting of this issue. His text thereby deserves a short excursus that will fit well into the problems and issues that have already been raised.

One can wholeheartedly agree with Caraway on several points raised against the scholars dealing with the audience commodity. Firstly, he claims this approach overstates the degree to which co-optation of audiences as a source of value and free labour is in fact realised, because the activities of audiences are not under the direct control of the capitalist (the audience commodity transaction). His second notion is connected to the first, namely that this approach and especially Smythe himself, completely lacks focus on subjectivities and their agency (theses of audience power and of 
media content as free lunch). Thirdly, there is a lack of focus on use-value. It is, however, crucial to ask, what is the epistemological approach of political economy and what is the subject matter these authors employ? - answers to which might clarify some of the dilemmas. Let us look at his arguments more closely, starting with the last one.

Caraway claims that "an exploration of the use-values derived by audiences from media products would have demonstrated the limits to capitalist domination in the sphere of production" (Caraway 2011,700 ). As mentioned earlier in this text, there are hardly any observations of use-value in the first volume of Capital. On the contrary, Marx focuses almost solely on exchange-value. He finds use-value as an almost irrelevant appendage, even talking about exchange-value simply as value. This is not because he personally feels use-value is irrelevant, but because this is how the capitalist economy operates. In A Contribution to the Critique of Political Economy, Marx even goes as far as to simply state that "use-value as such, lies outside the sphere of investigation of political economy", mainly because it is "a necessary prerequisite of the commodity" (Marx and Engels 1987, 270). And "since the use-value of the commodity is postulated, the specific utility and the definite usefulness of the labour expended on it is also postulated; but this is the only aspect of labour as useful labour which is relevant to the study of commodities" (Marx and Engels 1987, 277). Commodity must always posses some socially useful value, but its actual content is absolutely indifferent (Jameson 2011, 35-37) ${ }^{24}$. It is exactly this social (or socially relevant) character of usevalue of a certain commodity that makes it an exchangeable commodity, while at the same time, this characteristic also makes its actual content quite irrelevant as long as it has its consumers; basically anything can become commodified, as far as it has some use-value and as long as other people want it. Use-values provide commodities with commercial content, which makes them "material bearers of exchange-value". But "clearly, the exchange relation of commodities is characterised precisely by its abstraction from their use-values. Within the exchange relation, one use-value is worth just as much as another, provided only that it is present in the appropriate quantity" (Marx 1990/1867, 126f.). Exchange-value is a quantitative relation based in proportions and measurement, and for all we care, this can also be gossip on Lady Gaga's latest extravagance ... So far as society deems such use-values relevant enough to consume them.

Other authors, most notably Jhally (1987), have focused on the role of use-value in relation to commodity fetishism and the social construction of symbolic code (thus how meaning is produced for commodities), even though retaining a firmly materialist epistemological paradigm. Just because Smythe himself does not focus on this aspect (neither did Marx, for that matter), does not mean that his approach is not correct (he is just giving a certain perspective) or even that he saw no value in other perspectives, such as Jhally's. There were quite a number of attacks directed at Marx, claiming that he naturalised use-value and produced a fetishism of exchange. Such critiques are nothing new (for an overview and a defence of Marx, see, for example, Jhally 1987, 35), but could hardly be more unfair. Just because political economy does not concern itself with use-value does not mean use-value is socially irrelevant (quite the contrary).

Let us now turn to Caraway's two other points of critique: to what degree subjugation of audiences under capital is actually possible and what the role of agency is. He claims that neither in Smythe's nor in Jhally's and Livant's analysis can one find any "demonstration that the labour process described here [audience-labour] is under the control of the capitalist; nor is there any attempt to show that the use value is alienated from the audience" (Caraway 2011,697). He then presents new technologies of surveillance, but stresses it is necessary "to continually reassess the degree to which capital is able to bring these activities within the logic of accumulation. [...] The effectiveness of those efforts should be treated with a high degree of scepticism" (Caraway 2011, 698). He goes on to say that "the exact and dispassionate measurement of audiences is fiction" (Caraway 2011, 699).

It seems to me that Caraway is wrong in most of the issues raised. He is to an extent correct in saying that in the media relation, the capitalist does not directly control the labourer. That is of course true, but neither is the capitalist in the traditional production process able to fully control the labourer; the media owner is able to "buy" the interest of audiences with content and in both cases the labourer does not have that much of a choice if he wants to consume (there is of course always an option to turn off the TV, but it is an idealistic presumption that this somehow magically increases the power of audiences). In comparison to the labour process, the relationship here is definitely not so different. Labourers, much like audiences, can formally choose who they will work for; in reality however, their options are very limited in both cases. And owners in the media industry, much like traditional capitalists, know very well what they will be able to sell and how much they are

\footnotetext{
${ }^{24}$ Or to put it in Sohn-Rethel's words: "Commodity exchange requires, as a condition of its possibility, that the use of the commodities be suspended while they are subject to a transaction of exchange". (Sohn-Rethel's 1972, 51)
} 
able to spend so they remain profitable. If that was not the case, they would go out of business. The calculation is a pretty simple one and if it does not work out, the business cannot survive. No mystification is needed here; a capitalist will adapt his operation to the circumstances in which he has to operate. It is also leading readers astray by saying that in Smythe's formulation, "the audience does not appear as a seller of a commodity" (ibid., 697). Their commodity is the abstract time they are "selling" to the media owner in exchange for the content they receive, so to say their "freetime", leisure time. The use-value involved in this transaction is in fact irrelevant, but to go into detail, the use-values in the digitalised era are the personal characteristics (social status, interests, etc.) of the audiences that the media owner is able to sell to the advertiser (or quite simply, he sells their attention if these audiences are less differentiated) and most notably the content produced by audiences in digital environments. There is nothing unusual here that would not correspond to the Marxian analysis, neither is it completely true that "there is no formal contract, negotiation or discussion of terms between audience and advertiser" (Ibid.), which Caraway seems to feel is the crucial aspect of labour to appear as commodity (which is not the case; the sole precondition is the ability of the labourer to choose freely his exploiter when he puts his labour power in the labourmarket). Everything Caraway mentions in fact does happen, mostly informally, true, but on the Internet often also formally; for example via terms of use and privacy statements (see Sandoval 2012), while the negotiations are happening with mouse clicks or on the remote control. The consumer of the media content is able to change his "employer", and on the Internet, a person can easily self-employ himself by building his own website that will in real-life circumstances of course have immense difficulties of surviving against dominant actors such as Google or Facebook (just like it happens in the real-world economy).

Caraway's major problem throughout the text is that he fails to distinguish between two very different levels of argumentation: the abstract level and the concrete level. Both levels are of course of immense importance and the abstract argumentation, with its focus on tendencies, is built with the sole purpose of explaining the movement of concrete reality. The abstract argumentation however, which abstracts away particular cases and several mechanisms that operate in actually existing everyday life, can never fully explain concrete reality and particular cases, because its insight is limited (intentionally so). Causes for Marx's use of abstraction have been laid out earlier in this text, but one perhaps most obvious reason is that there is no way of analysing everything, dropping to the level of concrete reality, because this leaves the analyst with the sole focus on particular cases (such an analysis can bring a lot of new knowledge, but then again, also very little). As Collier (1994, 255-259) points out, apprehending the concrete whole is impossible and failing to realise this often makes us overlook crucial mechanisms and determinations (or we, at best, construct generalisations with little explanatory power $)^{25}$.

Caraway's inability to comprehend that political economy necessitates abstraction (together with focus on tendencies) is seen through his statement that "advertisers are not buying audience power but a fabricated image of an audience - and it is this fabrication which needs to be challenged by critical scholarship". Does he really believe advertisers do not know that? They are buying an approximation, an abstraction, a statistical construct of an audience and not "real" audiences: there is a relevant tendency (because of all the data they have) that the fabricated construct of an audience they bought will in large part behave in a way they planned that they will. In the abstract argument, they have to behave like that, otherwise the advertiser goes bankrupt; in the abstract reasoning this approximation must be close enough to reality in the long run to make it a reasonable purchase (it is not critical scholarship that factually risks its money by buying these fabrications; if this was not an economic practice that enhanced capitalists profitability, they would quite simply abandon it). It is very similar to a capitalist that is never able to know in advance whether he will be able to extract enough surplus value from the labour power he bought, so he is able to succeed on the market with the commodities which he plans to produce (the capitalist needs to speculate that he will be wily enough to control the labourer and extract enough surplus value). Similarly, looking at concrete examples, a capitalist in the production process never has complete control over the labourers he hired; in the worst case scenario (for him), labourers will go on strike. Or in the worst case scenario for the media owner, audiences will stop watching the content he is producing (which means he will either: put something else on-air, reduce costs so they correspond to the money brought in by the advertising, or go out of business). The abstract approach, of course, desubjectivises, but this is what capitalism in fact does: rationalising, objectifying, abstracting (see section 3.3).

\footnotetext{
${ }^{25}$ While it is true that the further away theory gets from the concrete toward the abstract, more prone to error it is, it should be noted that "in order to explain the concrete conjuncture we have to unravel by analysis (in thought) the multiple mechanisms and tendencies which make it what it is" (Collier 1994, 255).
} 
It is worth asking ourselves whether anyone, besides now mostly deceased Stalinist dialectical materialists, genuinely believes that Marx's quite apparent lack of interest in subjectivities and working-class power in some of his later writings, point at his disinterest in progressive changes in the world by these subjects? This would contradict much of his actual conduct throughout his whole life. It is, on the contrary, exactly because of his lack of attention toward subjectivities that he was able to analyse abstractly how the capitalist system in fact works (again, only at the abstract, not necessarily concrete level, where several other tendencies come into play, most importantly human agency that can resist this subjugation). He had to abstract from other aspects of concrete reality that are of prime importance to fight capitalism, to demonstrate how the capitalist exploits the worker in the production process if one accepts the ideal typology of the capitalist market constructed by classical political economists ${ }^{26}$. Abstraction offers both Marx and Smythe a specific perspective on how capitalism operates in an abstract form and it is obvious that this perspective is not complete; it leaves out vast parts of social life. It is an abstraction, a very important one, but still it is limited in its scope, which is a characteristic of any abstraction. Still, as Fuchs, for example, points out, Smythe in fact does not neglect agency, even if he finds no automatic resistance ${ }^{27}$. As Smythe points out in Dependency Road:

"True, people are subject to relentless pressures from Consciousness Industry; they are besieged with an avalanche of consumer goods and services; they are themselves produced as (audience) commodities; they reproduce their own lives and energies as damaged and in commodity form. But people are by no means passive or powerless. People do resist the powerful and manifold pressures of capital as best as they can. There is a dependable quantum of individual and group resistance, reproduced every day, arising out of people's innate capacity and need for love, respect, communal relations, and creativity. That is, the principal contradiction in the core area (as in the whole world) is that between people and capital. And presently people are the principal aspect of that contradiction"28. (Smythe 1981b, 270f.)

Caraway's notion on Smythe's purported ignorance of agency therefore does not seem valid. But even if it was, criticising an author who is deriving his research from a political economic perspective (consequently adopting a specific epistemological position) for not focusing on subjectivities, would seem similar to criticising a physician on the ground that he is not a chemist (or a carpenter, because he is not a plumber). One could give additional perspectives, but if he does not, why blame him because of it? Even though social sciences necessarily include several different perspectives, especially if they are critical, and must be aware of diverging analyses from different disciplines, distinction between different approaches and their subject matter is still important; in my opinion, it would be a mistake to simply conflate one approach with another, even if their contributions to the analysis of society may vary significantly.

Many authors - and Marx would probably be one of them, especially if one accepts Jameson's (2011, 37f.) central observation that Capital is in fact not a work of political action - would probably concur that focus on agency (e.g. resistance by differing subjectivities and possibilities of (counter) power produced by social movements) is simply not a subject matter of political economy (or its critique). In any case, political economy can or even must, however, be seen as one of the central preconditions for successful political action, touching on the need for redistribution of wealth and providing foundation to see clearly where wealth in fact originates from (human labour) ${ }^{29}$. There is no reason not to complement such a political-economic perspective with radical political theory if

\footnotetext{
${ }^{26}$ Let us take an obvious example, that of Adam Smith and his construction of social reality in The Wealth of Nations. The sheer fact his arguments are mostly abstractions tells us they cannot be refuted with practical examples (e.g. of the reputed failings of his theory when they are applied to concrete reality); even though we are yet to see such a perfectly competitive market, which is at the fundaments of his theory (arguably, there has never been such an example, especially not in the last century or so). (see also Harvey 2010)

${ }^{27}$ This thesis was raised in his plenary talk entitled Critique of the Political Economy of Social Media, which was given on $3^{\text {rd }}$ of May 2012 at the Critique, Democracy and Philosophy in 21st Century Information Society conference in Uppsala (Sweden). As he also pointed out in a private debate, Smythe's focus is, amongst others, on labour - and labour is an activity, it is inherently a place where active human subject comes in.

${ }^{28}$ This Smythe quote about agency was presented Fuchs in this talk at the Uppsala conference and taken from his presentation, see: http://www.scribd.com/doc/92818866/Christian-Fuchs-Critique-of-the-Political-Economy-of-Social-Mediaand-Informational-Capitalism. See also a forthcoming long contribution of Fuchs in tripleC (title:

Reloading Dallas Smythe: The Audience Commodity, the Digital Labour Debate, Marxist Political Economy, and Critical Theory Today).

${ }^{29}$ Barbalet $(1983,29-30)$ stresses that for Marx, abolition of social forms (such as commodity fetishism) requires social and political action, not scientific enquiry. Critical science is however an integral part of a wider revolutionary framework.
} 
one wishes (without seeking straw-man arguments or simple failings that are a consequence of abstraction). This is an approach of Negri and Hardt $(2001 ; 2005 ; 2009)$ and the whole autonomist line of thought (see Section 6). But agency and subjectivities are not a subject matter par excellence of political economy and in fact never were. They are a subject matter of (radical) political theory. Personally, I find it confusing when people for example claim Negri and Hardt have taken an easy path by ignoring the proletariat, instead focusing on the multitude, like it is an either-either choice. That is not the case. Similarly to the political-economic writings of Marx, in Negri and Hardt's works, the proletariat can be seen as a technical concept (just like several other concepts in Marx's writings are, for example commodity fetishism or exploitation, see also Harvey 2010). It is the type of reading that transforms them into political concepts. Autonomism for example offered a political reading of the concepts that were technical and constructed at the level of political economy (ibid.; Negri 1991/1984; Cleaver 2000/1979). Multitude (see Virno 2004; Hardt and Negri 2005) can on the other hand be seen as a concept derived from radical political theory that not by any chance contradicts or opposes the proletariat, but simply compliments one concept (derived from a certain field of study) with another. And neither does it exclude the other. My goal here is of course not to blindly defend the approach of political economy as the only correct one. On the contrary, I feel in many cases it has in fact been highly detrimental, providing only an "objectivistic" account by focusing on tendencies and mechanisms. Its basic premises should, however, be accepted as being valuable and credit should be given where credit is due: political readings of the central concepts in political economy would for example be impossible if Marx would not first provide us with a stringently technical, abstract, non-subjectivist and non-political reading.

\section{Communicative Capitalism and the Social Factory}

The key difference between the presented strands of the political economy of communication and post-operaist/autonomist neo-Marxism is that the latter expands its scope beyond media and communication (even if in some cases it takes examples from the Internet as case-studies). It also puts a much larger focus on the subjective agency; it is individual subjects that produce value and because value production has spread into wider society (e.g. the "social factory"), this offers a radical expansion for the political possibilities and human resistance against these processes.

Several findings and ideas on audience as commodity can be directly connected to this line of thought and we are able to see several convergence points between this critical theoretic approach and political economy of communication. Authors connected to this neo-Marxist "school" claim that communication, or even language-capacity as such, gained hegemonic primacy in contemporary society, therefore providing only one of the several possible links to political economy of communication. The concept of "social factory", which discloses how work has expanded beyond places commonly intended to host the production process (i.e., factory, manufacture ....) into wider society (see Negri 1984/1991; Negri 1992; Terranova 2004 etc.), also indirectly points at a full-fledged commodification of society, a thesis quite similar to those of Smythe and authors participating in the audience commodity debate.

Several authors such as Agamben (2000, 109-120), Virno (2004), Terranova (2004), Marazzi (2008), Negri (1991/1984; 1992; 1999) Negri and Hardt (2001; 2004; 2009), Dean (2008), Pasquinelli (2009), Gorz (2010), Fumagalli and Mezzadra (2010), Moulier Boutang (2011) and others have recently been writing on variations of communicative, cognitive or even semio and biolinguistic capitalism, where communication and language capacity are gaining in importance. They can even be seen as a deeper, ontological proposition on the species-being of human beings (see Dyer-Witheford 2004). Similar findings were applied before that by Lazzarato (1996), who wrote of immaterial labour. Later-on this type of labour was most carefully analysed by Gorz (2010). Gorz demonstrated how immaterial work has become the hegemonic form of work and the source for value creation in contemporary societies. Because of this transformation, people are totally subsumed under capital, where they must become the enterprises that they are, self-entrepreneurs, and must hold as much human capital as possible. "With self-entrepreneurship, whole persons and entire lives can, at last, be put to work and exploited. Life becomes 'the most precious capital'. The boundary between work and non-work fades, not because work and non-work activities mobilise the same skills, but because time for living falls, in its entirety, into the clutches of value" (Gorz 2010, 22; for an overview see Brophy and de Peuter 2007).

This is quite peculiar. It is important to note such an intertwinement between the time of labouring and non-labouring is very far from being common to capitalist societies. Quite on the contrary, with the rise of capitalism there was a radical separation between what was deemed productive (by capital), and what was unproductive, merely adequate for reproduction of human life. As Thompson (1967, 59f.; 1991, ch.6) demonstrates, task-orientated work and a hardly noticeable demarcation 
between "work" and "life" is distinctive of pre-capitalist communities, "where social intercourse and labour are intermingled - the working-day lengthens or contracts according to the task - and there is no great sense of conflict between labour and "passing the time of day"' (ibid., 60). Labour in capitalist societies, on the other hand, has historically always been stringently measured and timed by the clock (with far-reaching consequences). Thompson not only demonstrated that apprehension of time is socially constructed, but that linear measurement of time is crucial for capitalism. One of the pre-requisites of Marxian labour theory of value, which is constitutive for capitalist and exploitation of labour, is therefore being able to measure the labourers work. This is what abstract time is all about - even though capitalists have developed several new techniques of measuring, leading some authors to write about neo-Taylorism or digital Taylorism (e.g. Brown et al. 2011, ch.5). Nevertheless, this has important consequences, especially if we acknowledge there is an increasing number of jobs, where labour cannot be easily measured (see Gorz 1989). This often means neo-Taylorist practices are close to a mere façade, because they fail to measure anything of particular relevance. They are, however, effective means of surveillance and control over the workforce, as they were in the past. This difficulty is of course furthermore accentuated with the increasing blurring between time of labour and free-time. As noted by Postone (2003/1993, 26f.), "in the course of development of capitalist industrial production, value becomes less and less adequate as a measure of the 'real wealth' produced. [...] Value becomes anachronistic in terms of the potential of the system of production to which it gives rise; the realisation of that potential would entail the abolition of value". This means that "the abolition of value would signify that labour time no longer would serve as the measure of wealth and that the production of wealth no longer would be effected primarily by direct human labour in the process of production". For Postone it is therefore clear that "overcoming capitalism, according to Marx, entails a fundamental transformation of the material form of production, of the way people work".

It is not a historical novelty that much labour is done outside the production process or the places traditionally denoted as places for production (e.g. factory, manufacture). Such labour is however considered unproductive by capital and was often denoted as such also by "progressive" socialist movements, which excluded all but the "real proletariat", which was constituted by white men (see Huws 2003). These places were however at the same time crucial for reproduction of the lives of the labourers. This was especially the case with the unproductive labour done by women in the household, where this division was based on gender (for the role of this labour in the wider accumulation process see Wallerstein 1983, 22-28; Fortunati 1989; Huws 2003). According to Fortunati $(1989,9)$ the capitalist mode of production has a dual character, divided between production and reproduction. While the latter is deemed as a non-value (it is also non-waged and carried out in the home), the former supposedly produces value in the production process. Fortunati however twists this logic and demonstrates that reproduction is an integral part of the production process; in fact, "it clearly contributes to the creation of value as a crucial, integral part of the capitalist cycle" (Fortunati 1989,8$)$. It is an indirectly waged labour that is engaged in the reproduction of labour power, which is crucial for the production as such and simultaneously enables that two workers are exploited with one wage. This notion is today extended even further. Huws (2003, 27; 45f.; 68f.) for example uses terms "unpaid consumption labour" and "consumption workers" to denote many unprofitable tasks that are forced back on the consumer, adding to the unpaid labour common people must do to reproduce their labour power (and consequently their lives). This type of work has usually been done by women, who are disproportionately affected by these demands, reproducing the gender relations. The key novelty is that capital has been able to include this type of (what is known as) "economic externalities" into its accumulation cycle.

What is of particular interest to me here is not so much through what changes the conceptualisation of labour has gone and what the category of labour even means today. These can be indeed seen as crucial difficulties that political economy must face today. Neither do we want to focus on the structural transformations of capitalism in perhaps an entirely new phase of capitalism. What we want to consider here seems to be an equally important question, namely, "how far" commodification has been able to spread into lives of human beings, where and what it is able to colonise and under what conditions. We are able to see striking convergence points between early findings of Smythe and observations made by several strands of neo-Marxist critique of political economy when analysing not only the role of commodification in present historical moment, but also where capital is able to extract surplus value. There is no limit to the commodification process according to these two strands of thought and it is not a coincidence many critical communication scholars have integrated Autonomist perspective in their theoretical apparatus. It seems both strands fully demonstrate the real value of George Gerbner's statement from 1983 that "if Marx were alive to- 
day, his principal work would be entitled Communications rather than Capital" (cited in: Nordenstreng 2004, 13).

What is presently novel in contemporary societies is, as claimed by Autonomist authors, that capital is attempting to include in the capitalist accumulation circuit the sole human capabilities to produce knowledge, communicate, quickly adapt to changed conditions (flexibility), participate, or cooperate. These are capabilities that are specific to human beings, who, as open animals, are capable of constructing political and social institutions. These characteristics are being directly "employed" by contemporary capital through different techniques and apparatuses, which serve to extract value from living labour. This claim could even be seen as a naturally tendential development of capitalism, which cannot set itself any limits when colonising different spheres from which value can be extracted.

This is directly applicable to Virno's $(1996 ; 2004)$ reinterpretation of the concept of general intellect, derived from the "Fragment on the machines" in Marx's Grundrisse. Virno argues that postFordist capitalism mobilises all the faculties that characterise our species (i.e. language, abstract thinking, plasticity), a thesis that is derived from his social ontology. For Virno, for example, these capabilities can be seen as generically human: "post-Fordism mobilises all the faculties that characterise our species: language, abstract thinking, disposition toward learning, plasticity, the habit of not having solid habits" (Virno 2005, 29f.). It is these characteristics that are probably used in all professions and occupations (in the sense of the given definition communication is a necessary social manifestation of human language-capacity). Pasquinelli (2009) instead uses the term "common intellect", which demonstrates how capital is in fact exploiting human capabilities common to all people, while at the same time appropriating our common social production without paying for it (see also Hardt and Negri 2009).

As pointed out by Chicchi (2010), Marazzi (2010), or Vercelone (2010) financial capitalism has been able spread over the entirety of the economic accumulation cycle. In its fundamentals this means that finance is now present in all of the phases of economic cycle, from its start (production), to its end (consumption). This is the main reason why finance capitalism is able to extract value beyond areas that were traditionally meant for producing value (i.e. production of exchange value behind the borders of a factory). This simultaneously means commodification has been able to spread into all areas of life.

\section{Conclusion}

Several unresolved dilemmas have been posed throughout the text and more questions have been raised than answered. One of these is certainly in the category of labour: what does it encompass in the current historical context? It might be difficult for many to contemplate the idea that what is commonly considered as 'leisure time' can today be defined as a specific type of labour. My goal here was not to seek transhistorical, anthropological or essentialist definitions of a necessarily historical phenomenon - namely, labour in the context of a capitalist society. What should interest us is what capital deems as labour, no matter how implausible that particular type of labour or its products might seem to us personally (or even how superfluous one might feel these produced use-values are, because there is no real need to prove any of that, we just have to look at the most popular TV shows). Both political economy and its critique need, first and foremost, technical rather than moral definitions, which can enable a radical political resistance against capitalist subjugation. Can one go so far as to claim that any activity producing additional exchange-value for the owner of the commodity could be considered as some sort of labour (no matter what the magnitude of this added value might be)? This is not far from Marcuse's definition, which he derives from Marx's writings. He is defining the term labour "to mean what capitalism actually understands by it in the last analysis, that activity which creates surplus value in commodity production, or, which 'produces capital'" (Marcuse 1955, 293). Productivity in this sense is always something that is defined by the capital alone.

More detailed answers will have to wait for now, but what is important here is to acknowledge that big shifts, both at the social and at the economic level, have happened in the last decades and we lack acceptable answers and thorough analyses for many of them. Some indicators of these transformations have been given, through the problems and dilemmas raised in this text. We might therefore be able to provide a working thesis with regard to the all-encompassing commodification. This thesis needs to be further substantiated, but could offer a solid ground for a continuation of several ideas already raised regarding this issue:

The structural tendency of capitalism, which has developed into a world-integrated economic system, is not only to commodify and valorise all material and social as- 
pects of life, but also to incorporate human life as such (i.e. species-being) into its accumulation cycle: not only speech, but our ability to speak [logos], not only our feelings and emotions, but our generic human abilities for these activities. This tendency dictates that not a second of human life should be wasted by falling out of this economistic circuit of instrumental rationalisation and detailed calculation; every human act must be encompassed and every aspect of social life carefully measured.

Marx has been able to demonstrate the importance of the commodity-form and exchange for our social lives and individualisation. But the current phase of commodification goes much further than this; it starts to erode and change almost all human contacts and relations. It not only instrumentalises communication in the media, but could also infringe interpersonal communication, transforming humans into automatons. Where commodity starts to reign supreme over society, any possible independence of use-value is eradicated; anything socially useful that lacks exchange-value becomes worthless, dispensable, and irrelevant (what else is the real meaning of the draconian austerity cuts throughout the European Union?). What should worry us is not only social communication, which is possibly a somewhat abstract notion, but also the fundamental categories of democratic life. Information and communication cannot, without blinking, be seen just as one of the many types of commodities. They are crucial components of what we deem as free and democratic societies based on freedom from oppression and freedom of expression.

As Hanno Hardt $(2004,74)$ stressed, communication is central in most of the definitions of democracy with cogent reason. But can we really claim there is a freedom of expression if the whole communication process is turning into a big, interrelated and world-wide commodity chain, which has to play under "the coercive laws of competition" (Marx 1990/1867, 433): from the production (knowledge labour), to the content, infrastructure, and finally audiences - human beings? Is there any freedom when "creative, intellectual work turns into mass production, while individual ideas undergo ideological scrutiny to fit the demands of the market, where predictability and repetition are the key to commercial success" (Hardt 2004, 34)? In a time when the key communication channels and freedom of expression are in fact monopolised (or at best oligopolised) and owned by the smallest elite possible (McChesney 2008) ${ }^{30}$ ?

It is possible to claim that from its outset, critical theory has fought against instrumental reasoning and against positivist outlook on the world that does not reflect or critique this instrumentalisation of human beings and their relations (see Fuchs 2011, 11-26). Our task as critical theorists is to continuously provide a cogent critique of these processes. This is so especially because of the enduring instrumentalisation and economistic rationalisation, which is a consequence of total and seemingly unprecedented commodification in the history of capitalism. If we believe Wallerstein, however, there is at least one positive consequence of these processes: "Total commodification eventually removes the veils of the market". (Wallerstein 2001/1991, 25)

\section{References}

Adorno, Theodor W. 2001/1991. The Culture Industry: Selected Essays on Mass Culture. London, New York: Routledge. Agamben, Giorgio. 2000. Means Without Ends: Notes on Politics. Minneapolis, London: University of Minnesota Press.

Andrejevic, Mark. 2012. Exploitation in the Data Mine. In Internet and Surveillance: The Challenges of Web 2.0 and Social Media, edited by Christian Fuchs, Kees Boersma, Anders Albrechtslund, and Marisol Sandoval, 71-88. New York: Routledge.

Arendt, Hannah. 1998/1958. The Human Condition. $2^{\text {nd }}$ ed. Chicago, London: The University of Chicago Press.

Babe, Robert E. 2009. Cultural Studies and Political Economy: Toward a New Integration. Lanham, Boulder, New York: Lexington Books.

Balibar, Étienne. 2007. The Philosphy of Marx. London, New York: Verso.

Barbalet, Jack M. 1983. Marx's Construction of Social Theory. London, Boston [...]: Routledge and Keegan Paul.

Bellamy Foster, John and Robert McChesney. 2011. The Internet's Unholy Marriage to Capitalism. MRZine 62 (10). Available via: http://monthlyreview.org/2011/03/01/the-internets-unholy-marriage-to-capitalism (March 17, 2012).

Bermejo, Fernando. 2009. Audience Manufacture in Historical Perspective: from Broadcasting to Google. New Media and Society 11 (1-2): 133-154.

Biltereyst, Daniel and Philippe Meers. 2011. The Political Economy of Audiences. In The Handbook of Political Economy of Communications, edited by Janet Wasko, Graham Murdock and Helena Sousa, 415-435. Malden, Oxford: WileyBlackwell.

\footnotetext{
${ }^{30}$ McChesney goes even further, stressing that "the media have become a significant antidemocratic force in the United States. The wealthier and more powerful the corporate media giants have become, the poorer the prospects for participatory democracy". (McChesney 2008, 426) For Hardt, similarly, "the media have become part of the corporate domain of the American society which converts economic domination into political power. Thus, the media shape consciousness and help reinforce the dominant corporate ideology, which becomes the reigning political ideology". (Hardt 2004, 48)
} 
Bollier, David. 2002. Silent Theft: The Private Plunder of Our Common Wealth. New York, London: Pluto Press.

Bonefeld, Werner. 2001. The Permanence of Primitive Accumulation: Commodity Fetishism and Social Constitution. The Commoner 2: 1-15.

Boyle, James. 2008. The Public Domain: Enclosing the Commons of the Mind. New Haven, London: Yale University Press.

Brophy, Enda and Greig de Peuter. 2007. Immaterial Labour, Precarity, and Recomposition. In Knowledge Workers in the Information Society, edited by Catherine McKercher and Vincent Mosco, 177-192. Lanham: Lexington Books.

Brown, Phillip, Hugh Lauder, and David Ashton. 2011. The Global Auction: The Broken Promises of Education, Jobs and Incomes. Oxford, New York: Oxford University Press.

Caraway, Brett. 2011. Audience Labor in the New Media Environment: A Marxian Revisiting of the Audience Commodity. Media, Culture \& Society 33 (5): 693-708

Chicchi, Federico. 2010. On the Threshold of Capital, At the Thresholds of the Common. In Crisis in the Global Economy edited by Andrea Fumagalli Sandro Mezzadra, 139-152. New York: Autonomedia.

Cleaver, Harry. 2000/1979. Reading Capital Politically. Leeds: Anti/Theses.

Collier, Andrew. 1994. Critical Realism. London, New York: Verso.

De Angelis, Massimo. 2007. The Beginning of History: Value Struggles and Global Capital. London: Pluto Press.

Dean, Jodi. 2008. Communicative Capitalism: Circulation and the Foreclosure of Politics. In Digital Media and Democracy: Tactics in Hard Times, edited by Megan Boler, 101-121. Cambridge, London: MIT Press.

Debord, Guy. 1970. Society of Spectacle. Detroit: Black and Red Press.

Dyer-Witheford, Nick. 2004. 1844/2004/2044: The Return of Species-Being. Historical Materialism 12 (4): 3-26.

Eagleton, Terry. 1996. The Illusions of Postmodernism. Malden, Oxford: Blackwell.

Fiske, John. 1990. Introduction to Communication Studies. $2^{\text {nd }}$ edition. London, New York: Routledge.

Fleissner, Peter. 2009. The "Commodification" of Knowledge in the Global Information Society. tripleC - Cognition, Communication, Co-operation: Open Access Journal for a Global Sustainable Information Society 7 (2): 228-238.

Fortunati, Leopoldina. 1989. The Arcane of Reproduction: Housework, Prostitution, Labour and Capital. New York: Autonomedia.

Fuchs, Christian. 2010. Labor in Informational Capitalism and on the Internet. The Information Society 26 (3): 179-196.

Fuchs, Christian. 2011. Foundations of Critical Media and Information Studies. London, New York: Routledge.

Fuchs, Christian. 2012. Google Capitalism. tripleC - Cognition, Communication, Co-operation: Open Access Journal for a

Global Sustainable Information Society 10 (1): 42-48.

Fuchs, Christian, Kees Boersma, Anders Albrechtslund, and Marisol Sandoval, eds. 2012. Internet and Surveillance: The Challenges of Web 2.0 and Social Media. New York: Routledge.

Fumagalli, Andrea and Sandro Mezzadra, eds. 2010. Crisis in the Global Economy. New York: Autonomedia.

Gandy, Oscar H. Jr. 2012. Matrix Multiplication and the Digital Divide. In Race After the Internet, edited by Lisa Nakamura and Peter A. Chow-White, 128-145. New York, London: Routledge.

Gorz, André. 1989. Critique of Economic Reason. London, New York: Verso.

Gorz. André. 2010. The Immaterial. London: Seagull Books.

Gramsci, Antonio. 1971. Selections from the Prison Notebooks. London: Lawrence and Wishart.

Hardt, Hanno. 2004. Myths for the Masses: An Essay on Mass Communication. Malden, Oxford, Victoria: Blackwell Publishing.

Hardt, Michael and Antonio Negri. 2001. Empire. Cambridge: Harvard Univ. Press.

Hardt, Michael and Antonio Negri. 2004. Multitude: War and Democracy in the Age of Empire. New York: The Penguin Press.

Hardt, Michael and Antonio Negri. 2009. Commonwealth. Cambridge, Massachusetts: The Belknap Press of Harvard University Press.

Harvey, David. 1996. Justice, Nature and the Geography of Difference. Cambridge: Blackwell.

Harvey, David. 2003. The New Imperialism. Oxford, New York: Oxford University Press.

Harvey, David. 2010. A Companion to Marx's Capital. London, New York: Verso.

Hindman, Matthew. 2009. The Myth of Digital Democracy. Princeton in Oxford: Princeton Press.

Hobsbawm, Eric. 2011. How to Change the World: Reflections of Marx and Marxism. New Haven, London: Yale University Press.

Horkheimer, Max and Theodor Wiesengrund Adorno. 2002/1947. Dialectic of Enlightenment: Philosophical Fragments. Stanford, California: Stanford University Press.

Huws, Ursula. 2003. The Making of a Cybertariat: Virtual Work in a Real World. New York: MR Press.

Innis, Harold Adams. 2008/1951. The Bias of Communication. $2^{\text {nd }}$ ed. Toronto: Univ. of Toronto Press.

Jameson, Fredric. 2009. Valences of the Dialectic. London, New York: Verso.

Jameson, Fredric. 2011. Representing Capital: A Reading of Volume One. London, New York: Verso.

Jhally, Sut. 1987. The Codes of Advertising: Fetishism and the Political Economy of Meaning in the Consumer Society. New York: Routledge.

Kang, Hyunjin and Matthew P. McAllister. 2011. Selling You and Your Clicks: Examining the Audience Commodification of Google. tripleC - Cognition, Communication, Co-operation: Open Access Journal for a Global Sustainable Information Society 9 (2): 141-153.

Lazzarato, Maurizio. 1996. Immaterial Labour. In Radical Thought in Italy: A Potential Politics, edited by Paolo Virno and Michael Hardt, 133-147. Minneapolis and London: Minnesota University Press.

Lefebvre, Henri. 1968. The Sociology of Marx. New York: Pantheon Books.

Lukács, Georg. 1971. History and Class Consciousness: Studies in Marxist Dialectics. Cambridge, Massachusets: The MIT Press.

Marazzi, Christian. 2008. Capital and Language: From the New Economy to the War Economy. Los Angeles: Semiotext(e).

Marazzi, Christian. 2010. The Violence of Financial Capitalism. Los Angeles: Semiotext(e).

Marcuse, Herbert. 1955. Reason and Revolution: Hegel and the Rise of Social Theory. $2^{\text {nd }}$ ed. London: Routledge \& Keegan Paul Ltd.

Marx, Karl. 1993/1858. Grundrisse: Foundations of the Critique of Political Economy (Rough Draft). London: Penguin Books.

Marx, Karl. 1990/1867. Capital: A Critique of Political Economy, Volume One. London: Penguin Books.

Marx, Karl. 1991/1894. Capital: A Critique of Political Economy, Volume Three. London: Penguin Books.

Marx, Karl and Frederick Engels. 1975. Collected Works, Volume 3 (1843-1844). London: Lawrence \& Wishart. 
Marx, Karl and Frederick Engels. 1976. Collected Works, Volume 6 (1845-1848). New York: International Publishers.

Marx, Karl and Frederick Engels. 1987. Collected Works, Volume 29 (1857-1861). New York: International Publishers.

Maxwell, Rick. 1991. The Image is Gold: Value, The Audience Commodity, and Fetishism. Journal of Film and Video 43 (12): $29-45$

May, Christopher. 2010. The Global Political Economy of Intellectual Property Rights: The New Enclosures. $2^{\text {nd }}$ ed. New York: Routledge.

McChesney, Robert W. 2008. The Political Economy of Media. New York: Monthly Review Press.

Meehan, Eileen. 1993. Commodity Audience, Actual Audience: The Blindspot Debate. In Illuminating the Blindspots: Essays Honoring Dallas W. Smythe, edited by Janet Wasko, Vincent Mosco, and Manjunath Pendakur, 378-400. New Jersey: Ablex.

Mezzadra, Sandro. 2011. The Topicality of Prehistory: A New Reading of Marx's Analysis of "So-Called Primitive Accumulation". Rethinking Marxism 22 (3): 302-321.

Mosco, Vincent. 2009. The Political Economy of Communication. $2^{\text {nd }}$ edition. Los Angeles, London: Sage.

Mosco, Vincent and Catherine McKercher. 2008. The Laboring of Communication: Will Knowledge Workers of the World Unite? Lanham, Boulder, New York: Lexington Books.

Moulier Boutang, Yann. 2011. Cognitive Capitalism. Cambridge, Malden: Polity Press.

Murdock, Graham. 1978. Blindspots about Western Marxism: A Reply to Dallas Smythe. Canadian Journal of Political and Social Theory 2 (2): 109-119.

Murdock, Graham. 2006. Marx on Commodities, Contradictions and Globalisations Resources for a Critique of Marketised Culture. E-Compós 7: 1-23.

Murdock, Graham. 2011. Political Economies as Moral Economies: Commodities, Gifts, and Public Goods. In The Handbook of Political Economy of Communications, edited by Janet Wasko, Graham Murdock, and Helena Sousa, 13-40. Malden, Oxford: Wiley-Blackwell.

Murdock, Graham and Peter Golding. 1973. For a Political Economy of Mass Communications. The Socialist Register 10: 205-234

Napoli, Philip M. 2010. Revisiting 'Mass Communication' and the 'Work' of Audience in the New Media Environment. Media, Culture and Society, 32 (3): 505-516.

Napoli, Philip M. 2011. Audience Evolution: New Technologies and the Transformation of Media Audiences. New York: Columbia University Press.

Negri, Antonio. 1991/1984. Marx Beyond Marx: Lessons on the Grundrisse. London: Pluto Press.

Negri, Antonio. 1992. Interpretation of the Class Situation Today: Methodological Aspects. In Open Marxism, Volume 2: Theory and Practice, edited by Werner Bonefeld, Richard Gunn, and Kosmas Psychopedis, 69-105. London: Pluto Press.

Negri, Antonio. 1999. Value and Affect. Boundary 226 (2): 77-88.

Nightingale, Virginia, ed. 2011. The Handbook of Media Audiences. Malden, Oxford: Wiley-Blackwell.

Nordenstreng, Kaarle. 2004. Ferment in the Field: Notes on the Evolution of Communication Studies and its Disciplinary Nature. The Public - Javnost 11 (3): 5-18.

Parker, lan. 1994. Commodities as Sign-Systems. In Information and Communication in Economics, edited by Robert E. Babe, 69-91. Boston Dordrecth, London: Kluwer Academic Publishers.

Pasquinelli, Matteo. 2009. Google's PageRank Algorithm: A Diagram of Cognitive Capitalism and the Rentier of the Common Intellect. In Deep Search: The Politics of Search Beyond Google, edited by Konrad Becker and Felix Stalder. London: Transaction Publishers. Available via: http://matteopasquinelli.com/docs/Pasquinelli_PageRank.pdf (April 1, 2012)

Perelman, Michael. 2000. The Invention of Capitalism: Classical Political Economy and the Secret History of Primitive Accumulation. Durham, London: Duke University Press.

Polanyi, Karl. 2001/1944. The Great Transformation: The Political and Economic Origins of Our Times. Boston: Beacon Press.

Postone, Moishe. 2003/1993. Time, Labor, and Social Domination: A Reinterpretation of Marx's Social Theory. Cambridge: Cambridge Univesity Press.

Prodnik, Jernej. 2011. Permanentnost primitivne akumulacije, ali: o privatni lastnini, komodifikaciji in povratku rente [eng.: The Permanence of Primitive Accumulation, or: On the Private Property, Commodification and Return of the Rent]. Casopis za kritiko znanosti 244: 89-109.

Prodnik, Jernej. 2012. Toward a Critique of Surveillance in the Age of the Internet: A Reflection on the "Internet and Surveillance" Volume Edited by Fuchs, Boersma, Albrechtslund, and Sandoval. tripleC - Cognition, Communication, Cooperation: Open Access Journal for a Global Sustainable Information Society 10 (1): 92-99.

Sandoval, Marisol. 2012. A Critical Empirical Case Study of Consumer Surveillance on Web 2.0. In Internet and Surveillance: The Challenges of Web 2.0 and Social Media, edited by Christian Fuchs, Kees Boersma, Anders Albrechtslund, and Marisol Sandoval, 147-169. New York: Routledge.

Schiller, Herbert I. 1989. Culture, Inc.: The Corporate Takeover of Public Expression. New York, Oxford: Oxford University Press.

Smythe, Dallas W. 1960. On the Political Economy Of Communications. Journalism Quarterly (Fall), 563-572.

Smythe, Dallas W. 1977. Communications: Blindspot of Western Marxism. In Counterclockwise: Perspectives on Communication, edited by Thomas Guback, 266-291. Boulder, San Francisco, Oxford: Westview Press.

Smythe, Dallas W. 1978. Rejoinder to Graham Murdock. In Counterclockwise: Perspectives on Communication, edited by Thomas Guback, 292-301. Boulder, San Francisco, Oxford: Westview Press.

Smythe, Dallas W. 1981a. Communications: Blindspot of Economics. In Culture, Communication, and Dependency: The Tradition of H.A. Innis, edited by William H. Melody, Liora Salter and Paul Heyer, 111-126. New Jersey: Ablex.

Smythe, Dallas W. 1981b. Dependency Road: Communications, Capitalism, Consciousness, and Canada. New Jersey: Ablex Publishing.

Sohn-Rethel, Alfred. 1972. Mental and Manual Labour in Marxism. In Situating Marx, edited by Paul Walton and Stuart Hall, 44-71. London: Human Context Books.

Sohn-Rethel, Alfred. 1978. Intellectual and Manual Labour: A Critique of Epistemology. London, Basingstoke: The MacMillan Press Ltd.

Terranova, Tiziana. 2004. Network culture: Politics for the information age. London: Pluto Press.

Thompson, Edward Palmer. 1967. Time, Work-Discipline, and Industrial Capitalism. Past and Present 38: 56-97.

Thompson, Edward Palmer. 1991. Customs in Common. London: Merlin Press.

Huws, Ursula. 2003. The Making of a Cybertariat: Virtual Work in Real World. New York: Monthly Review Press. 
Vercellone, Carlo. 2010. The Crisis of the Law of Value and the Becoming-Rent of Profit. In Crisis in the Global Economy edited by Andrea Fumagalli Sandro Mezzadra, 85-118. New York: Autonomedia.

Virno, Paolo. 1996. Notes on the "General Intellect". In Marxism beyond Marxism, edited by Saree Makdisi, Cesare Casarino and Rebecca E. Karl, 265- 272. New York, London: Routledge.

Virno, Paolo. 2004. A Grammar of the Multitude: For an Analysis of Contemporary Forms of Life. Semiotext(e), Los Angeles and New York.

Virno, Paolo. 2005. Interview with Paolo Virno (by Branden W. Joseph). Grey Room 21: 26-37.

Wallerstein, Immanuel. 1983. Historical Capitalism. London: Verso.

Wallerstein, Immanuel. 2001/1991. Unthinking Social Science: The Limits of Nineteenth-Century Paradigms. $2^{\text {nd }}$ ed. Philadelphia: Temple University Press.

Wasko, Janet. 2005. Studying the Political Economy of Media and Information. Communicaçao e Sociedade 7: 25-48.

Wasko, Janet, Graham Murdock, and Helena Sousa, eds. 2011. The Handbook of Political Economy of Communications. Malden, Oxford: Wiley-Blackwell.

Williams, Raymond. 1973. Base and Superstructure in Marxist Cultural Theory. New Left Review 82: 3-16.

Williams, Raymond. 2005/1980. Culture and Materialism. London: Verso.

\section{About the Author}

Jernej Prodnik

is a Researcher at the Social Communication Research Centre and Assistant to the Teaching Process at the Media Studies department (Faculty of Social Sciences, University of Ljubljana, Slovenia). His main research interests include structural transformations of post-Fordist capitalist societies, critique of political economy (focusing especially on communication), and wider social context of technological changes and democratic potentials brought by new technologies (including edemocracy and e-participation). 